\title{
Temperature-growth divergence in white spruce forests of Old Crow Flats, Yukon Territory, and adjacent regions of northwestern North America
}

Post-print/Accepted manuscript

Trevor J. Porter

Michael F.J. Pisaric

Porter, T. J. and Pisaric, M. F. J. (2011). Temperature-growth divergence in white spruce forests of Old Crow Flats, Yukon Territory, and adjacent regions of northwestern North America. Glob. Change Biol., 17: 3418-3430. doi:10.1111/j.1365-2486.2011.02507.x

This is the peer reviewed version of the following article: Porter, T. J. and Pisaric, M. F. J. (2011). Temperature-growth divergence in white spruce forests of Old Crow Flats, Yukon Territory, and adjacent regions of northwestern North America. Glob. Change Biol., 17: 3418-3430, which has been published in final form at doi:10.1111/i.1365-2486.2011.02507.x This article may be used for non-commercial purposes in accordance with Wiley Terms and Conditions for Self-Archiving.

\section{HOW TO CITE TSPACE ITEMS}

Always cite the published version, so the author(s) will receive recognition through services that track citation counts, e.g. Scopus. If you need to cite the page number of the TSpace version (original manuscript or accepted manuscript) because you cannot access the published version, then cite the TSpace version in addition to the published version using the permanent URI (handle) found on the record page. 
1 Temperature-growth divergence in white spruce forests of Old Crow Flats, Yukon Territory, and

2 adjacent regions of northwestern North America

3

$4 \quad$ Trevor J. Porter* and Michael F.J. Pisaric

5

6 Department of Geography and Environmental Studies, Carleton University, 1125 Colonel By

7 Drive, Ottawa, Ontario, Canada, K1S 5B6

8

9 *Corresponding author: +1-613-520-2600 ext. 1836, +1-613-520-4301 (fax),

10 tjporter@connect.carleton.ca

11

12 Keywords: dendroclimatology, ring-width, divergence, boreal treeline, white spruce, Old Crow

13 Flats, Yukon Territory

14

15

16

17

18

19

20

21

22

23 
We present a new 23-site network of white spruce ring-width chronologies near boreal treeline in Old Crow Flats, Yukon Territory, Canada. Most chronologies span the last 300 years, 27 and some reach the mid- $16^{\text {th }}$ century. The chronologies exhibit coherent growth patterns before the 1930s. However, since the 1930s they diverge in trend and exhibit one of two contrasting, but well-replicated patterns we call Group 1 and Group 2. Over the instrumental period (19302007) Group 1 sites were inversely correlated with previous-year July temperatures while Group 2 sites were positively correlated with growth-year June temperatures. At the broader northwestern North America (NWNA) scale, we find that the Group 1 and Group 2 patterns are common to a number of white spruce chronologies, which we call NWNA 1 and NWNA 2 chronologies. The NWNA 1 and NWNA 2 chronologies also share a single coherent growth pattern prior to their divergence ( 1950s). Comparison of the NWNA 1/NWNA 2 chronologies against gridded $20^{\text {th }}$-century temperatures for NWNA and reconstructed Northern Hemisphere summer temperatures (A.D. 1300-2000) indicates that all sites responded positively to spatial extent of divergence implies a large-scale forcing. As the divergence appears to be restricted to the $20^{\text {th }}$ century, we suggest the temperature response shift represents a moisture stress caused by an anomalously warm, dry $20^{\text {th }}$-century climate in NWNA, as indicated by

43 paleoclimatic records. However, because some sites do not diverge, and are located within a few 44 kilometres of divergent sites, we speculate that site-level factors have been important in 45 determining the susceptibility of sites to the large-scale drivers of divergence. 


\section{Introduction}

In high-latitude regions, dendroclimatic studies often report a positive relation between summer temperatures and tree-ring width (e.g., Briffa et al. 1990; Szeicz and MacDonald 1995; Gostev et al. 1996; D’Arrigo et al. 2006; Frank et al. 2007; Wilson et al. 2007; Youngblut and Luckman 2008). This observed relation is intuitive for trees living at the cold northern margins of the boreal forest where tree growth is largely thought to be temperature-dependent; however, this is not always the case. In northwestern North America (NWNA), in particular, many white spruce (Picea glauca [Moench] Voss) stands are inversely correlated with previous-year summer temperature (e.g., Barber et al. 2000; Lloyd and Fastie 2002; Wilmking et al. 2004; Pisaric et al. 2007; McGuire et al. 2010). At some of these sites, inverse relations may have persisted over the entire $20^{\text {th }}$ century (Lloyd and Bunn 2007), but at others they appear to be a recent phenomenon (Jacoby and D'Arrigo 1995; D’Arrigo et al. 2004). Similar temperature response shifts are also found at high-latitude Eurasian sites (Briffa et al. 1998; Jacoby et al. 2000). Collectively, these instances of transient temperature-growth responses are referred to as the 'Divergence Problem' (DP) (D’Arrigo et al. 2008).

In a paleoclimatology context, DP complicates the use of affected tree-ring chronologies as temperature proxies since reconstructions depend on time-stable proxy-climate relations.

However, because high-latitude tree-ring networks are an important data source for centennialto millennial-length temperature reconstructions (Jansen et al. 2007), it is important to improve understandings of DP and the extent to which past climate-growth relations can be considered time-stable.

The divergence problem is often observed as a low-frequency departure between summer temperature and ring-width/density occurring after the mid- to late- $20^{\text {th }}$ century (D'Arrigo et al. 
70 2008), coinciding with the warmest period the Arctic has experienced in the last two millennia

71 (Kaufman et al. 2009). Although the cause(s) of DP are largely unknown, many have suggested

72 the relatively warm late- $20^{\text {th }}$ century may be driving this non-linear behaviour by temperature-

73 induced drought stress (Jacoby and D’Arrigo 1995; Barber et al. 2000; Lloyd and Bunn 2007;

74 McGuire et al. 2010) or optimal biological temperature thresholds being surpassed (D'Arrigo et

75 al. 2004; Wilmking et al. 2004). Other possible explanations for DP include late-20 ${ }^{\text {th }}$-century

76 changes in snow cover (Vaganov et al. 1999), UV-B radiation (Briffa et al. 2004), and global

77 dimming (D'Arrigo et al. 2008). However, current understandings of DP are based on a small

78 number of study sites, limiting our ability to draw conclusions about its causes and the likelihood

79 that past temperature-growth relations were also impacted.

80 Here we present a new network of site-averaged ring-width chronologies from 23 white

81 spruce sites in Old Crow Flats, Yukon Territory, Canada, to satisfy 3 objectives: (1) expand the

82 high-latitude tree-ring network into a region where this research has been absent; (2) examine the 83 response of this network to temperature; and (3) determine if trees in this region were impacted

84 by DP. Further, we draw comparisons between these results and a larger-scale network of white

85 spruce sites across NWNA. Old Crow Flats hosts the northernmost extent of boreal treeline in

86 Yukon Territory and is adjacent to interior Alaska, central Yukon, and the Mackenzie Delta,

87 areas where divergence has been identified (D'Arrigo et al. 2004; Wilmking et al. 2004; Pisaric

88 et al. 2007). Our site chronology network is unique in NWNA due to its very high site density.

89 This characteristic allows us to better identify regionally-significant growth patterns that are

90 more closely linked to regional-scale factors such as climate than any individual site chronology

91 (Hughes 2011). 


\section{Materials and methods}

94

Study region

The Old Crow Flats region (Fig. 1) is a low-lying basin complex bounded by mountain ranges in Alaska and Yukon Territory. The region's surficial geology is primarily defined by a thick glaciolactustrine clay unit deposited by Glacial Lake Old Crow when it occupied the area from 24,000-12,000 years BP (Hughes 1972; Morlan 1980; Thorson and Dixon 1983; Dyke et al. 2002). Much of the region is poorly drained and covered by a vast mosaic of shallow lakes and peatlands (Ovenden and Brassard 1989; Labreque et al. 2009). Meandering channels incise the surficial clay and provide some drainage (Lauriol et al. 2002). Channel floodplains are well drained and covered by thick organic layers underlain by fine-to-coarse fluvial deposits (Hughes, 1971). White spruce forests in the region are generally found on floodplains while black spruce (Picea mariana [Mill.] BSP) forests tend to occupy poorly drained areas amongst the lakes.

Old Crow Flats is in the continuous permafrost zone (Heginbottom et al. 1995). Climate is highly seasonal (Fig. 2) with dry, stable Arctic air dominating during winter, and relatively warm, moist air from the North Pacific and Beaufort Sea during summer (Dyke 2000). Mean annual, winter (Dec.-Feb.), and summer (Jun.-Aug.) temperatures at Old Crow are $-9.0^{\circ} \mathrm{C}$, $28.6^{\circ} \mathrm{C}$, and $12.6^{\circ} \mathrm{C}$, respectively (www.climate.weatheroffice.gc.ca). Minimum (maximum) temperatures are below freezing for all months except June-August (May-September) (Fig. 2). Despite its abundance of lakes, annual precipitation at Old Crow Flats is low compared to other northern regions with only parts of the Canadian Arctic Archipelago and northern Greenland receiving less precipitation per annum (Serreze and Barry 2005). Old Crow receives $265 \mathrm{~mm}$ of precipitation annually, $\sim 38 \mathrm{~mm}$ during winter, and $\sim 119 \mathrm{~mm}$ in summer (Fig. 2). 


\section{Tree-ring data}

Twenty-three white spruce stands were sampled in 2007 and 2008 (Fig. 1a); all sites are within $150 \mathrm{~km}$ of latitudinal treeline. General sampling locations were preselected so that sites would be distributed across the region. In the field, mature sites were preferentially sampled to maximize the length of resultant tree-ring chronologies. Mature sites were identified based on tree morphology and abundance of deadwood. All sites shared a similar open canopy structure such that light could easily penetrate to ground level, and a comparable assemblage of shrubs, mosses, grasses, and lichens. All sites except TM2 and SC1 are situated on channel floodplains. TM2 is situated on a hill known locally as Timber Hill and faces south-west; SC1 is a relatively high-elevation site ( $\sim 647 \mathrm{~m}$ a.s.1. compared to $\sim 267 \mathrm{~m}$ a.s.1. on average for the other sites; Table 1) in the Old Crow Range and faces north-east. The remaining sites have no particular aspect.

On average, 33 trees were sampled per site, most of which $(\sim 80 \%)$ were living. Standard dendrochronology techniques were used to collect and prepare tree-ring samples for ring-width measurement (Speer 2010). Rings were visually cross-dated and measured using a Velmex treering measuring system (precise to $0.001 \mathrm{~mm}$ ). Two radii per tree were measured in all but a few cases. Cross-dating accuracy was verified with the computer program COFECHA (Holmes 1983). Age-related trends were removed from raw data using conservative negative exponential or negative/zero slope linear curve fits (Fritts et al. 1969). A 'signal-free' beta version of the computer program ARSTAN (courtesy of Ed Cook, Lamont-Doherty Earth Observatory Tree-

Ring Lab, pers. comm.) was used to calculate standard tree-ring indices according to the 'signalfree standardisation' approach described by Melvin and Briffa (2008); mean site chronologies were calculated using the robust bi-weight mean (Cook 1985). Signal-free standardisation was used instead of traditional standardisation because it is ideally suited to avoid 'trend-distortion,' 
an effect that concentrates towards the modern ends of tree-ring series and results in a distorted climate signal in mean tree-ring chronologies (Melvin and Briffa 2008). For some of our sites, trend distortion would be a valid concern if signal-free methods were not used (SI-Figs. 1 and 2).

\section{Temperature-growth analysis}

The Old Crow climate record is relatively short (1951-2007) and incomplete. To support a longer comparison with our tree-ring data, we developed a regional composite temperature record from nearby stations including Fairbanks and Fort Yukon in interior Alaska, and Inuvik, Aklavik, and Fort McPherson in the Mackenzie Delta region of Northwest Territories (Fig. 1b). These records compare well with the Old Crow record in terms of trend and interannual variability, and can be used to estimate regional temperatures. Alaskan data were provided by the Alaska Climate Research Center (M. Shulski, 2008, pers. comm.) and Canadian data were obtained from Environment Canada (www.climate.weatheroffice.ec.gc.ca). These records were averaged by region for interior Alaska and the Mackenzie Delta (following normalization), and the regional means were then combined to create a monthly minimum, mean, and maximum temperature record for the larger region centered on Old Crow Flats. The regional composite spans 1930-2007 (pre-1930 data were not used due to limited spatial coverage) and is well correlated with minimum, mean, and maximum temperatures at Old Crow $(\mathrm{r}=0.88,0.91$, and 0.88 , respectively, for the average month; $\mathrm{p} \leq 0.001)$.

Growth-year and previous-year May-August temperatures (1930-2007) were compared to each of the 23 site chronologies to determine their dominant response to temperature. Pearson's Product-Moment Correlation Coefficients (r-values) were used to quantify these relations. Sites that shared a common temperature response were averaged into mean regional chronologies to 
162 enhance the common signal and then examined for signs of DP as observed in neighbouring

163 regions.

164

165

166

167

168

169

170

171

172

173

174

175

176

177

178

179

180

181

182

183

184 


\section{Results}

Temperature-growth relations in Old Crow Flats

Correlations between our 23 mean site chronologies and the regional temperature record reveal two primary, and distinctly opposite responses to summer temperature (Table 2). In general, all sites are best correlated with June/July temperatures, but roughly half correlate negatively and the other half positively with June/July temperatures (Table 2). The negatively correlated sites exhibit their strongest correlations with maximum July temperatures of the previous year, while the positively correlated sites exhibit their strongest correlations with minimum June temperatures of the growth year. Sites with the negative/positive temperature response are hereafter referred to as 'Group 1'/'Group 2' sites (Table 2). Only one site, DP21, had a 'mixed' temperature relation, albeit weak, and could not be differentiated as either Group 1 or Group 2 (Table 2). Since our primary focus is regionally-significant growth responses to temperature, we focus on the Group 1 and Group 2 chronologies that are of greater regional importance.

\section{Group 1/Group 2 regional growth patterns}

The distinction between Group 1 and Group 2 sites is clear in terms of correlation with summer temperature (Table 2). In terms of growth index, there are many notable differences and similarities between Groups 1 and 2 (Fig. 3a, b) which we emphasize by comparing the mean Group 1 and Group 2 chronologies (Fig. 3c; mean Group 1/Group 2 chronologies calculated for all years defined by 2 or more site chronologies). The mean Group 1 and Group 2 chronologies are highly coherent over the period $1620-1800$, as demonstrated by a strong running correlation coefficient (Fig. 3c; see SI-Fig. 3a for a magnified comparison). 
Both groups began the $19^{\text {th }}$ century at their lowest index values on record and maintained 209 similar growth levels until $\sim 1850$ before following an upward trend into the $20^{\text {th }}$ century (Fig.

$2103 c$ ). However, Group 1 began its upward trend slightly before Group 2 (as early as 1825/1875

211 for Group 1/Group 2) causing a systematic offset between them until the mid-20 ${ }^{\text {th }}$ century (Fig.

212 3c; see SI-Fig. 3b for a magnified comparison). The significance of these differences was tested

213 using a running 2-sample t-test (see SI-Note 1). Significant $(\mathrm{p} \leq 0.05)$ differences between the

214 Group 1 and Group 2 chronologies are found during 63\% of years from 1866-1948. However,

215 despite these growth index differences, their respective linear trends were indistinguishable over

216 the period 1866-1948 (+0.043/+0.042 index values per decade for Group 1/Group 2) leading to a

217 strong, stable running correlation (Fig. 3c; mean $r=0.82$ ).

218 Important differences emerge after the 1930s. Group 1 reaches its highest growth values

219 on record in the 1930s (SI-Fig. 3; 1926-1935 mean index =1.2) and then declines towards low

220 values in the 1980 s. Conversely, Group 2 maintains a positive trend throughout the $20^{\text {th }}$ century

221 and reaches record high growth values at present (SI-Fig. 3; 1998-2007 mean index = 2.0).

222 Effectively, this opposing behaviour equates to a 'growth-trend divergence' that is evident in the

223 running correlation which drops below the $\mathrm{p} \leq 0.05$ significance level in 1953 , reaching its

224 lowest point $(\mathrm{r}=-0.02)$ in 1966 (Fig. 3c). Group 1 growth trends become positive after the

225 1980s contributing to a small rise in correlation with Group 2. By 1972, correlations become

226 significant again, but remain low relative to pre-1930 correlations (Fig. 3c).

227 While the Group 1 and Group 2 chronologies are very different in the 'low-frequency'

228 domain since the 1930s, the two groups are coherent at higher-frequencies over all periods. To

229 demonstrate this, we compared high-pass filtered mean Group 1 and Group 2 chronologies (40-

230 year cubic smoothing spline; see Cook and Peters 1981) and found that both groups exhibited the 
231 same high-frequency growth variations over the last 400 years, even after the post-1930s growth 232 trend divergence described above (Fig. 3d).

Group 1/Group 2 vs. temperature

As with their constituent site chronologies, the mean Group 1 and Group 2 chronologies

236 are most strongly correlated with previous-year July maximum and growth-year June minimum

237 temperatures, respectively (Table 2). A visual comparison of the mean group chronologies

238 versus their most closely associated temperature index shows no apparent signs of temperature-

239 growth divergence during recent decades of the $20^{\text {th }}$ century (Fig. 4), as observed in other parts

240 of NWNA. From the 1930s to 1980s, Group 1 growth declined as July maximum temperatures

241 increased, but rebounded from the 1980s to present as July temperatures cooled slightly (Fig. 4).

242 Contrary to July maximum temperatures, June minimum temperatures have increased steadily

243 since the 1930s, a trend that is matched by the Group 2 growth response (Fig. 4).

244

Larger-scale significance of Group 1/Group 2

246 To determine if the contrasting Group 1 and Group 2 growth patterns are simply a local

247 phenomenon or reflective of larger-scale growth patterns, a number of long white spruce ring-

248 width chronologies from adjacent parts of NWNA (Fig. 5) were obtained from the International

249 Tree Ring Databank (ITRDB; http://www.ncdc.noaa.gov/paleo/treering.html) and other sources

250 (Table 3), and compared to the mean Group 1 and Group 2 chronologies. Only chronologies

251 spanning 1700-1975 were considered in order to assess long-term coherence. Also, a number of

252 spatial criteria were considered to determine which sites were used. To avoid sites with a strong

253 maritime climate (e.g., Gulf of Alaska coastline; see L'Heureux et al. 2004, Serreze and Barry 
2542005 ), only sites above $65^{\circ} \mathrm{N}$ were used. The latitudinal range of sites extends eastward from the 255 west coast of Alaska to $115^{\circ} \mathrm{W}$. This spatial range coincides with sites near boreal treeline where 256 tree growth is expected to be temperature-limited. The ITRDB has 26 chronologies matching 257 our spatiotemporal criteria (Fig. 5; Table 3). Further, we use 2 'sub-population' chronologies 258 developed from hundreds of white spruce trees at several sites in the Mackenzie Delta (Pisaric et 259 al. 2007; Fig. 5; Table 3). All 28 'NWNA chronologies' were processed using signal-free 260 standardisation as outlined in the Methods section. The NWNA chronologies were considered comparable to Group 1 and Group 2 if they met the following criteria: (1) correlates positively and significantly ( $\mathrm{p} \leq 0.01)$ with both Group 1 and Group 2 from 1850-1930; and (2) correlates positively and significantly with only one of

264 Group 1 or Group 2 from 1930-present. Based on these criteria, 14 NWNA chronologies are not 265 similar to Group 1 or Group 2 (Table 3; sites 02-03, 05-13, 15, 18, \& 25), 11 of which (sites 02$26603, \& 05-13)$ are clustered in a small area ( $\sim \mathrm{km}$ radius) on the Seward Peninsula, Alaska. Of 267 the remaining 14 NWNA chronologies, 7 are similar to Group 1: sites 14, 17, 19-21, \& 23-24

268 (Table 4); hereafter, we refer to these chronologies, including the mean Group 1 chronology, as 269 'NWNA 1 chronologies' (Fig. 6a). The other 7 NWNA chronologies are similar to Group 2: 270 sites $01,04,16,22, \& 26-28$ (Table 4). These chronologies, plus the mean Group 2 chronology, 271 are now referred to as 'NWNA 2 chronologies' (Fig. 6b). 273 observation seen with the Old Crow Flats tree-ring data. NWNA 1 and NWNA 2 had a coherent 274 growth pattern from A.D. 1550 until the mid-20 $0^{\text {th }}$ century, after which the mean chronologies 275 diverge from one another (Fig. 6c). This is reflected in the strong running correlation from 15502761930 and the subsequent decline to non-significant values by 1957 (Fig. 6c). Unlike with Group 
2771 and Group 2, NWNA 1 and NWNA 2 have little offset from 1866-1948 (Fig. 6c); only 10\% of

278 the years over this period are significantly different based on a running 2-sample t-test (SI-Note

279 1). A second important difference between the Old Crow Flats and the NWNA chronologies is

280 that the timing of mid-20 $0^{\text {th }}$-century divergence differs slightly. NWNA 1 sites do not peak until

$281 \sim 1950$ s, which is roughly 2 decades later than the Group 1 sites in Old Crow Flats. Lastly, as we

282 found in Old Crow Flats, high-frequency growth patterns at the NWNA-scale were coherent over

283 all periods (Fig. 6d) suggesting that growth trend divergence is exclusively a low-frequency

284 phenomenon.

285

286

NWNA 1/NWNA 2 vs. temperature

287 Given their similarity to Group 1/Group 2, it seems plausible that NWNA 1/NWNA 2

288 may also represent negative/positive responses to $20^{\text {th }}$-century summer temperature. Indeed, this

289 idea is supported by independent climate-growth analyses for several of the NWNA 1/NWNA 2

290 site chronologies (Szeicz and MacDonald 1994, 1996; D’Arrigo et al. 2004; Pisaric et al. 2007;

291 Visser et al. 2010). At broader scales, this is supported by correlations between the mean

292 NWNA 1/NWNA 2 chronologies and a composite of gridded mean monthly temperatures for the

293 greater NWNA region derived from the CRUTEM3v dataset (Brohan et al. 2006; see SI-Note 3

294 for details on the composite).

295

Overall, NWNA 1 sites were most strongly and negatively correlated with previous-year

296 July temperatures over the last century (1900-2003), as with Group 1 in Old Crow Flats (Table

297 5). However, NWNA 1's temperature-growth relation was not stable over the $20^{\text {th }}$ century as

298 demonstrated by a split-period analysis (Table 5). NWNA 1 sites shared a significant positive

299 relation with growth-year June/July average temperatures in the early-20 ${ }^{\text {th }}$ century (1900-1950), 
300 and a significant inverse relation with prior-year July temperatures in the late-20 ${ }^{\text {th }}$ century (1951-

301 2003) (Table 5). This transition from a positive to negative temperature response is effectively

302 illustrated with a plot of NWNA 1 versus June/July temperatures (Fig. 7). However, because of

303 the gradual, low-frequency nature of the change, and of the temperature-growth relation itself, it

304 is difficult to pinpoint the timing of temperature-growth divergence with any precision. Based

305 on a visual inspection of the data, the early-1960s appear to be a reasonable approximation (Fig.

306 7). Conversely, NWNA 2 sites responded positively to growth-year June/July temperatures

307 during both the early- and late-20 th century (Table 5; Fig. 7).

308

Long-term temperature-growth relations in NWNA

As both NWNA 1 and NWNA 2 had a positive temperature response before the mid-20 century, it seems likely that the NWNA 1 growth pattern represents an anomalous temperature

312 response. Although, this idea lacks long-term verification from NWNA instrumental data which 313 are largely restricted to the $20^{\text {th }}$ century. Alternatively, a simple comparison against the mean of 3146 Northern Hemisphere (NH) temperature reconstructions since A.D. 1300 provides independent 315 verification (Fig. 8a, b). NWNA 1 and NWNA 2 track NH temperatures well before the mid-20 316 century (Fig. 8b) suggesting their pre-divergence growth was a positive function of temperature.

317 We do note that some site chronologies that constitute the mean NWNA chronologies were also 318 used in some of the NH reconstructions; however, the contribution of the shared chronologies to 319 the overall variance of the NH reconstructions is negligible. In other words, virtually all of the 320 coherence between NWNA 1/NWNA 2 and NH temperatures is from independent data. Finally, 321 as was the case with NWNA 1 versus NWNA temperatures (Fig. 7), NWNA 1 failed to track NH 322 temperatures since the mid-20 $0^{\text {th }}$ century (Fig. 8). 


\section{Discussion}

324

Implications and timing of growth trend divergence

Here we have provided evidence of widespread growth trend divergence in NWNA. Our Group 1 and Group 2 chronologies showed similar growth patterns prior to the 1930s, but one of two contrasting patterns since. This growth trend divergence (negative/positive trends) is the main distinction between Group 1 and Group 2 since the 1930s. At larger scales, this growth trend divergence was replicated using 14 white spruce chronologies across NWNA, although the timing of divergence was the 1950s. The coherence of these chronologies before divergence implies that they were responding to a similar regional climatic factor; however, their contrasting behaviour since implies that one of the groups diverged from its former response to climate.

Due to the instrumental data limitations in Old Crow Flats we could not directly assess the implied climate-growth response change for Group 1/Group 2 sites. Yet, the NWNA-scale analysis did reveal that NWNA 1 sites transitioned from a positive to negative temperature response in the mid- $20^{\text {th }}$ century, while NWNA 2 sites maintained a stable positive temperature response throughout the $20^{\text {th }}$ century. A comparison against reconstructed Northern Hemisphere temperatures confirmed that all sites, including NWNA 1 sites, shared a positive temperature response prior to $20^{\text {th }}$-century divergence.

As reported elsewhere (Jacoby and D’Arrigo 1995; Briffa et al. 1998; Cook et al. 2004; D'Arrigo et al. 2004; D'Arrigo et al. 2008), our NWNA-scale results largely support the idea that temperature-growth divergence is a mid- $20^{\text {th }}$-century phenomenon. However, there does appear to be some variability in timing. For example, in Old Crow Flats Group 1/Group 2 sites began to trend in opposite directions as early as the 1930s. Briffa et al. (1998) and Pisaric et al. (2007) also found that some regions may have diverged in the 1930s. 
On a more cautious note, there is some indication that Group 1 sites began to separate

347 from Group 2 sites in terms of temperature sensitivity during the $19^{\text {th }}$ century given their offset

348 index values thereafter. At the NWNA-scale, this offset was less apparent, but it was evident.

349 Similarly, sub-population (i.e., intra-site dynamics) studies in Alaska have also found evidence

350 of growth pattern divergence during the $19^{\text {th }}$ century (Wilmking et al. 2004). However, in Old

351 Crow Flats, we remain cautious of labelling this offset a true temperature-growth divergence

352 given that Group 1 and Group 2 have virtually identical linear trends over their period of offset.

353 This parallel behaviour suggests Group 1 and Group 2 responded to climate in the same manner

354 over this period, but that they had slight differences in terms of climatic sensitivity. Further, we

355 cannot discount the possibility it is a detrending artefact due to the difficulty in separating age-

356 related trend from two very different externally-forced $20^{\text {th }}$-century growth patterns, one peaking

357 in the 1930s and another with a strong late-century increase. Regardless of its nature, the offset

358 does not imply a major change in temperature-growth response. By contrast, $20^{\text {th }}$-century

359 growth trend divergence implies a temperature-growth response reversal for some sites.

Long-term stability of temperature-growth relations

The divergence problem has been the subject of on-going research for nearly 2 decades

363 (D'Arrigo et al. 2008). From a paleoclimatology perspective, it is important to better understand 364 the spatiotemporal extent of the phenomenon, its causes, and the likelihood it has impacted past 365 growth. In turn, such insight would help determine the extent to which affected chronologies can 366 be used to provide robust estimates of past temperature. Current understandings of DP remain 367 tenuous due to the limited number of datasets affected by divergence and the collinearity of 368 potential contributing environmental factors (D'Arrigo et al. 2008). However, a growing body of 
369 evidence suggests that DP may be caused by the anomalously warm temperatures of the $20^{\text {th }}$

370 century (Jacoby and D’Arrigo 1995; Barber et al. 2000; D’Arrigo et al. 2004; Wilmking et al.

371 2004; Pisaric et al. 2007) which likely have been unmatched in the last 2000 years (Kaufman et

372 al. 2009).

373 The idea that DP is unique to the $20^{\text {th }}$ century does have some empirical support. Based

374 on their comparison of divergent northern site chronologies with a number of other temperature

375 sensitive hemispheric chronologies, Cook et al. (2004) concluded that $20^{\text {th }}$-century DP is unique

376 in the context of the last 1100 years. Similarly, our comparison of the NWNA chronologies to

377 reconstructed $\mathrm{NH}$ temperatures suggests that $20^{\text {th }}$-century divergence is unique in the context of

378 the last 700 years, at least. In fact, the coherence between the NWNA 1/NWNA 2 chronologies

379 and $\mathrm{NH}$ temperatures prior to divergence is remarkable considering the spatial-scale differences

380 (i.e., NWNA vs. NH) and the well documented regional-heterogeneity of NH temperatures over

381 past centuries (D’Arrigo et al. 2006; Mann et al. 2009). One notable exception occurs during the

382 late 1400s when the NWNA chronologies indicate a cool period. This period corresponds with

383 the well known Spörer minimum (Stuiver 1961; Bard et al. 2001), one of the longest and most

384 pronounced solar minima of the past millennium.

385

Large-scale drivers of divergence

387 Our results support the notion that DP in NWNA is unique to the $20^{\text {th }}$ century suggesting 388 that DP was caused by a large-scale environmental or climatic change that is also unique to the $38920^{\text {th }}$ century. Several large-scale factors have been proposed including: temperature-induced 390 drought stress (Jacoby and D’Arrigo 1995; Barber et al. 2000; Lloyd and Fastie 2002; Wilmking 391 and Juday 2005; McGuire et al. 2010), biological temperature thresholds (D’Arrigo et al. 2004; 
392 Wilmking et al. 2004), snow cover changes (Vaganov et al. 1999), UV-B changes (Briffa et al.

393 2000), and global dimming (D'Arrigo et al. 2008). Depending on the region, DP may have been

394 caused by one, all, or a combination of these factors. However, negative temperature-growth

395 relations in NWNA have been linked to regional moisture gradients (Wilmking and Juday 2005;

396 Lloyd and Bunn 2007) implying that the divergence may be caused by moisture stress. NWNA

397 is already limited in terms of its annual precipitation budget, and the strong $20^{\text {th }}$-century warming 398 in this region (ACIA 2005) has likely placed an even greater moisture limitation on these forests.

399 We also introduce another large-scale factor that may have contributed to DP in NWNA,

400 but has been absent in discussions of DP: Pacific derived moisture. Directional warming was

401 one of the most prominent climate system changes following the mid-19 ${ }^{\text {th }}$ century in high-

402 latitude regions (Overpeck et al. 1997; Kaufman et al. 2009). However, in NWNA, this warming 403 was accompanied by important moisture changes towards interior NWNA (Anderson et al. 2007, 404 2011) due to a major atmospheric circulation reorganisation linked to the strength of the Aleutian 405 Low (Fisher et al. 2004; Anderson et al. 2005). This transition led to a relatively dry $20^{\text {th }}$ century 406 in many parts of interior NWNA compared to the last 1200 years (Fisher et al. 2004; Anderson et 407 al. 2011). This reorganisation appears to have been widespread as it coincides with several other 408 large climate system changes in Pacific basin (e.g., Thompson et al. 1986; Mann et al. 2000;

409 Hendy et al. 2002). Although we cannot say which large-scale factor ultimately caused some 410 sites to diverge, several moisture related factors may be involved including temperature-induced 411 drought stress and reduced Pacific-derived moisture since the mid-19 ${ }^{\text {th }}$ century. 
415 by a large-scale forcing. However, not all sites were affected, some of which are found within a

416 few kilometres of sites that were affected (e.g., DP30 vs. DP31, or DP23-26 vs. DP27; SI-Fig. 4).

417 Therefore, it is also clear that site-specific factors determine how each site has been impacted by

418 putative large-scale forcing that caused DP. Ecological factors may be particularly important.

419 For example, Wilmking and Juday (2005) reported that sites with lower tree densities tended to

420 have a greater proportion of trees that responded positively to temperature, presumably related to

421 soil moisture competition.

Organic layer thickness may also be important. At a white spruce stand in the Mackenzie

423 Delta, King (2009) found that trees with a positive temperature-growth response were linked to

424 thicker surficial organic layers that maintain cooler active layers and limit direct evaporative

425 moisture loss from the soil. Negative temperature responses were linked to a thinner organic

426 layer and warmer active layer. A larger-scale study of black spruce in western Quebec, Canada,

427 by Drobyshev et al. (2010) also supports the notion that surficial organic layer thickness may

428 lead to contrasting climate-growth responses (see also Nilsson and Wardle 2005; Turetsky et al.

4292010 on the importance of the organic layer in boreal ecosystem functioning). The contribution

430 of such site-level (or intra-site) factors to DP has not been examined in detail, but presents an

431 exciting research opportunity to better understand the spatial complexity of tree growth

432 responses in high-latitude boreal ecosystems.

433

434

435

436 


\section{Concluding remarks}

The Divergence Problem has been an ongoing issue for dendroclimatologists working in

439 high-latitude regions for the past 16 years. Because of the limited number of datasets affected by

440 DP, progress in characterizing and advancing current understandings of it has been slow. In this

441 study, we made a sizeable contribution to the high-latitude tree-ring network, adding 23 new

442 white spruce chronologies from Old Crow Flats, northern Yukon. Further, we draw comparisons

443 between these sites and 14 other long white spruce chronologies from across NWNA and shed

444 new light on potential causes of DP. Our results suggest that white spruce temperature-growth

445 divergence in NWNA largely began in the 1950s, and as early as the 1930s in Old Crow Flats. A

446 long-term comparison of NWNA chronologies against reconstructed Northern Hemisphere

447 temperatures provides good independent verification of the idea that these chronologies

448 responded positively to temperature since A.D. 1300, and that temperature-growth divergence in

449 NWNA is probably restricted to the $20^{\text {th }}$ century.

450 The large spatial extent of sites that were impacted by DP suggests a large-scale forcing

451 was the cause. As DP occurs during the warmest period of the last 2000 years (Kaufman et al.

452 2009) it is likely temperature-induced drought stress is involved. A strengthened Aleutian Low

453 since the mid-19 ${ }^{\text {th }}$ century (Fisher et al. 2004; Anderson et al. 2005), which led to anomalously

454 dry $20^{\text {th }}$-century conditions in interior NWNA (Anderson et al. 2011), may also be a contributing

455 factor. However, considering the proximity of divergent and non-divergent sites in our network,

456 we speculate that site-specific factors (e.g., organic layer thickness; King 2009; Drobyshev et al.

457 2010) have an overarching role in determining the susceptibility of individual sites to DP. 
460

461

462 conduct this research in Old Crow Flats. We also thank: D. Maxwell, P. deMontigny, A. Burn,

463 P. Miller, E. Tizya-Tramm, T. Green for field/lab support; G. King, S. St. George for comments

464 on earlier drafts of this paper; E. Cook for a 'signal-free' version of ARSTAN; the contributors

465 of ITRDB data used here; and two anonymous reviewers whose comments helped improve this

466 manuscript considerably. This research was supported by: a NSERC Discovery Grant, NSERC

467 Northern Supplement and Government of Canada IPY grant to M. Pisaric; and a NSERC

468 Graduate Scholarship and Northern Scientific Training Program grant to T. Porter.
469

470

471

472

473

474

475

476

477

478

479

480

481

482 
483

484

485

486

487

488

489

490

491

492

493

494

495

496 497 Reviews, 30, 887-898.

498

499 Barber VA, Juday GP, Finney BP (2000) Reduced growth of Alaskan white spruce in the 500 twentieth century from temperature-induced drought stress. Nature, 405, 668-673.

501

502

503

504

ACIA (2005) Arctic Climate Impact Assessment. Cambridge University Press, New York, NY, USA, $1042 \mathrm{pp}$.

Anderson L, Abbott MB, Finney BP, Burns SJ (2005) Regional atmospheric circulation change in the North Pacific during the Holocene inferred from lacustrine carbonate oxygen isotopes, Yukon Territory, Canada. Quaternary Research, 64, 21-35.

Anderson L, Abbott MB, Finney BP, Burns SJ (2007) Late Holocene moisture balance variability in the southwest Yukon Territory, Canada. Quaternary Science Reviews, 26, 130-141.

Anderson L, Finney BP, Shapley MD (2011) Lake carbonate- $\delta^{18} \mathrm{O}$ records from the Yukon Territory, Canada: Little Ice Age moisture variability and patterns. Quaternary Science

Bard E, Raisbeck G, Yiou F, Jouzel J (2000) Solar irradiance during the last 1200 years based on cosmogenic nuclides. Tellus, 52B, 985-992. 
521

522

523

524 USA, 171 pp.

526 Cook ER, Esper J, D'Arrigo RD (2004) Extra-tropical Northern Hemisphere land temperature 527 variability over the past 1000 years. Quaternary Science Reviews, 23, 2063-2074. 
529 Cook ER, Peters K (1981) The smoothing spline: a new approach to standardizing forest interior 530 tree-ring width series for dendroclimatic studies. Tree-Ring Bulletin, 41, 45-53.

531

532 D'Arrigo R, Kaufmann RK, Davi N, Jacoby GC, Laskowski C, Myneni RB, Cherubini P (2004)

533 Thresholds for warming-induced growth decline at elevational tree line in the Yukon Territory,

534 Canada. Global Biogeochemical Cycles, 18, GB3021, doi:10.1029/2004GB002249.

535

536

D'Arrigo R, Wilson R, Jacoby G (2006) On the long-term context for late twentieth century

537 warming. Journal of Geophysical Research, 111, D03103, doi:10.1029/2005JD006352.

538

539 D'Arrigo R, Wilson R, Liepert B, Cherubini P (2008) On the 'Divergence Problem' in Northern

540 Forests: A review of the tree-ring evidence and possible causes. Global and Planetary

541 Change, 60, 289-305.

542

543 Drobyshev I, Simard M, Bergeron Y, Hofgaard A (2010) Does soil organic layer thickness affect

544 climate-growth relationships in the black spruce boreal ecosystem? Ecosystems, 13, 556-574.

545

546 Dyke AS, Andrews JT, Clark PU, England JH, Miller GH, Shaw J, Veillette JJ (2002) The

547 Laurentide and Innuitian ice sheets during the Last Glacial Maximum. Quaternary Science

548 Reviews, 21, 9-31.

549 
550 Dyke LD (2000) Climate of the Mackenzie River valley. In: The Physical Environment of the

551 Mackenzie Valley, Northwest Territories: A Baseline for the Assessment of Environmental

552 Change (eds Dyke LD, Brooks GR), pp. 21-30. Geological Survey of Canada, Ottawa, Ontario.

553

554 Esper J, Cook ER, Schweingruber FH (2002) Low-frequency signals in long tree-ring

555 chronologies for reconstructing past temperature variability. Science, 295, 2250-2253.

556

557 Fisher DA, Wake C, Kreutz K et al. (2004) Stable isotope records from Mount Logan, Eclipse

558 ice cores and nearby Jellybean Lake. Water cycle of the North Pacific over 2000 years and over

559 five vertical kilometers: Sudden shifts and tropical teleconnections. Géographie Physique et

560 Quaternaire, 58,9033-9048.

561

562 Frank D, Esper J, Cook ER (2007) Adjustment for proxy number and coherence in a large-scale 563 temperature reconstruction. Journal of Geophysical Research, 34, L16709, 564 doi:10.1029/2007GL030571.

565

566 Fritts HC, Moismann JE, Bottorff CP (1969) A revised computer program for standardizing tree567 ring series. Tree-Ring Bulletin, 29, 15-20.

568

569 Gostev M, Wiles G, D’Arrigo R, Jacoby G, Khomentovsky P (1996) Early summer temperatures

570 since 1670 A.D. for Central Kamchatka reconstructed based on a Siberian larch tree-ring width

571 chronology. Canadian Journal of Forest Research, 26, 2048-2052.

572 
573 Heginbottom JA, Dubreuil MA, Harker PA (1995) Canada - Permafrost. In: National Atlas of

574 Canada, 5th Edition. Plate 2.1, scale 1:7,500,000 (MCR 4177) Natural Resources Canada,

575 Ottawa, Canada.

576

577 Hendy EJ, Gagen MK, Alibert CA, McColloch MT, Lough JM, Isdale PJ (2002) Abrupt

578 decrease in tropical Pacific sea surface salinity at the end of the Little Ice Age. Science, 295,

$579 \quad 1511-1514$.

580

581 Holmes RL (1983) Computer-assisted quality control in tree-ring dating and measurement. Tree-

$582 \quad$ Ring Bulletin, 43, 69-78.

583

584 Hughes MK (2011) Dendroclimatology in High-Resolution Paleoclimatology. In:

585 Dendroclimatology: Progress and Prospects (eds Hughes MK, Swetnam TW, Diaz HF), pp. 17-

586 34. Springer, New York.

587

588 Hughes OL (1972) Surficial geology of northern Yukon Territory and northwestern District of

589 Mackenzie, Northwest Territories. Geological Survey of Canada Paper 69-36, 11.

590

591 Hughes OL, Rampton VN (1971) Northern Yukon Territory, and Northwestern District of

592 Mackenzie. Geological Survey of Canada, Surficial Geology Map 1319A (1:500,000).

593

594 Jacoby GC, D'Arrigo RD (1995) Tree ring width and density evidence of climatic and potential

595 forest change in Alaska. Global Biogeochemical Cycles, 9, 227-234. 
597 Jacoby GC, Lovelius NV, Shumilov OI, Raspopov OM, Karbainov JM, Frank DC (2000) Long-

598 term temperature trends and tree growth in the Taymir Region of Northern Siberia. Quaternary

$599 \quad$ Research, 53, 312-318.

600

601 Jansen E, Overpeck J, Briffa KR et al. (2007) Palaeoclimate. In: Climate Change 2007: The

602 Physical Science Basis. Contribution of Working Group I to the Fourth Assessment Report of the

603 Intergovernmental Panel on Climate Change (eds Solomon S, Qin D, Manning M, Chen Z,

604 Marquis M, Averyt KB, Tignor M, Miller HL), Cambridge University Press, Cambridge, United

605 Kingdom and New York, NY, USA.

606

607 Jones PD, Briffa KR, Barnett TP, Tett SFB (1998) High-resolution palaeoclimatic records for the

608 last millennium: interpretation, integration and comparison with General Circulation Model

609 control-run temperatures. The Holocene, 8, 455-471.

610

611 Kaufman DS, Schneider DP, McKay NP et al. (2009) Recent warming reverses long-term Arctic

612 cooling. Science, 325, 1236-1239.

613

614 King GM (2009) Factors influencing the growth of white spruce (Picea glauca) in the Mackenzie

615 Delta, NT. Carleton University, Unpublished M.Sc. thesis in Geography, Ottawa, Canada, 159

$616 \mathrm{pp}$.

617 
618 Labrecque S, Lacelle D, Duguay CR, Lauriol B, Hawkings J (2009) Contemporary (1951-2001)

619 evolution of lakes in the Old Crow Basin, northern Yukon, Canada: remote sensing, numerical 620 modelling, and stable isotope analysis. Arctic, 62, 225-238.

621

622 Lauriol B, Duguay CR, Riel A (2002) Response of the Porcupine and Old Crow rivers in 623 northern Yukon, Canada, to Holocene climatic change. The Holocene, 12, 27-34.

624

625 L'Heureux ML, Mann ME, Cook BI, Gleason BE, Vose RS (2004) Atmospheric circulation 626 influences on seasonal precipitation patterns in Alaska during the latter 20th century. Journal of 627 Geophysical Research, 109, D06106, doi:10.1029/2003JD003845.

628

629 Lloyd AH, Bunn AG (2007) Responses of the circumpolar boreal forest to 20th century climate 630 variability. Environmental Research Letters, 2,doi:10.1088/1748-9326/2/4/045013.

631

632 Lloyd AH, Fastie CL (2002) Spatial and temporal variability in the growth and climate response 633 of treeline trees in Alaska. Climatic Change, 52, 481-509.

634

635 Mann ME, Bradley RS, Hughes MK (2000) Long-term variability in El-Niño-Southern 636 Oscillation and associated teleconnections. In: El Niño and the Southern Oscillation (eds Diaz 637 HF, Markgraf V), pp. 357-412. Cambridge University Press, New York, USA. 638

639 Mann ME, Zhang Z, Rutherford S et al. (2009) Global signatures and dynamical origins of the 640 Little Ice Age and Medieval Climate Anomaly. Science, 326,1256-1260. 
642 McGuire AD, Ruess RW, Lloyd A, Yarie J, Clein JS, Juday GP (2010) Vulnerability of white 643 spruce tree growth in interior Alaska in response to climate variability: dendrochronological, 644 demographic, and experimental perspectives. Canadian Journal of Forest Research, 40, 11976451209.

646

647 Melvin TM, Briffa KR (2008) A "signal-free" approach to dendroclimatic standardisation.

648 Dendrochronologia, 26, 71-86.

649

650 Morlan RE (1980) Taphonomy and archaeology in the upper Pleistocene of the northern Yukon 651 Territory: a glimpse of the peopling of the New World. Archaeological Survey of Canada, Paper 652 no. 94, 398.

653

654 Nilsson M-C, Wardle DA (2005) Understorey vegetation as a forest ecosystem driver: evidence 655 from the northern Swedish boreal forest. Frontiers in Ecology and the Environment, 3, 421-428. 656

657 Ovenden J, Brassard GR (1989) Wetland vegetation near Old Crow, northern Yukon. Canadian 658 Journal of Botany, 67, 954-960.

659

660 Overpeck J, Hughen KA, Hardy D et al. (1997) Arctic environmental change of the last four 661 centuries. Science, 278, 1251-1256. 
663 Pisaric MFJ, Carey SK, Kokelj SV, Youngblut D (2007) Anomalous 20th century tree growth,

664 Mackenzie Delta, Northwest Territories, Canada. Geophysical Research Letters, 34, L05714, 665 doi:10.1029/2006GL029139.

666

667 Serreze MC, Barry RG (2005) Physical characteristics and basic climatic features. In: The Arctic

668 Climate System pp. 17-54. Cambridge University Press, Cambridge, UK.

669

670 Stuiver M (1961) Variations in radiocarbon concentration and sunspot activity. Journal of

671 Geophysical Research, 66, 273-276.

672

673 Speer JH (2010) Fundamentals of Tree-Ring Research. University of Arizona Press, Tucson, 674 Arizona, $252 \mathrm{pp}$.

675

676 Szeicz JM, MacDonald GM (1996) A 930-year ring-width chronology from moisture-sensitive

677 white spruce (Picea glauca Moench) in northwestern Canada. The Holocene, 6, 345-351.

678

679 Szeicz JM, MacDonald GM (1995) Dendroclimatic reconstruction of summer temperatures in

680 northwestern Canada since A.D. 1638 based on age-dependent modelling. Quaternary

681 Research, 44, 257-266.

682

683 Szeicz JM, MacDonald GM (1994) Age-dependent tree-ring growth responses of subarctic white 684 spruce to climate. Canadian Journal of Forest Research, 24, 120-132.

685 
695

696

697 698

699

700

701

702

703

704

705

706

707 708

Thompson LG, Mosely-Thompson E, Dansgaard W, Grootes PM (1986) The Little Ice Age as recorded in the stratigraphy of the tropical Quelccaya Ice Cap. Science, 234, 361-354.

Thorson RM, Dixon EJ (1983) Alluvial history of the Porcupine River, Alaska: role of glaciallake overflow from northwest Canada. Geological Society of America, 94, 576-589.

Turetsky MR, Mack MC, Hollingsworth TN, Harden JW (2010) The role of mosses in ecosystem succession and function in Alaska's boreal forest. Canadian Journal of Forest Research, 40, 1237-1264.

Vaganov EA, Hughes MK, Kirdyanov AV, Schweingruber FH, Silkin PP (1999) Influence of snowfall and melt timing on tree growth in subarctic Eurasia. Nature, 400, 149-151.

Visser H, Büntgen U, D'Arrigo R, Petersen AC (2010) Detecting instabilities in tree-ring proxy calibration. Climate of the Past Discussions, 6, 225-255.

Wahl ER, Ammann CM (2007) Robustness of the Mann, Bradley, Hughes reconstruction of Northern Hemisphere surface temperatures: Examination of criticisms based on the nature and processing of proxy climate evidence. Climatic Change, 85, 33-69.

Walker DA, Raynolds MK, Daniëls FJA et al. (2005) The Circumpolar Arctic vegetation map. Journal of Vegetation Science, 16, 267-282. 
709 Wilmking M, Juday GP (2005) Longitudinal variation of radial growth at Alaska's northern

710 treeline - recent changes and possible scenarios for the 21st century. Global and Planetary

711 Change, 47, 282-300.

712

713 Wilmking M, Juday GP, Barber VA, Zald HSJ (2004) Recent climate warming forces

714 contrasting growth responses of white spruce at treeline in Alaska through temperature

715 thresholds. Global Change Biology, 10, 1724-1736.

716

717 Wilson R, D'Arrigo R, Buckley B et al. (2007) A matter of divergence: tracking recent warming

718 at hemispheric scales using tree ring data. Journal of Geophysical Research, 112, D17103,

719 doi:10.1029/2006JD008318.

720

721 Youngblut D, Luckman B (2008) Maximum June-July temperatures in the southwest Yukon

722 over the last 300 years reconstructed from tree rings. Dendrochronologia, 25, 153-166.

723

724

725

726

727

728

729

730

731 
732 Table 1. White spruce sites sampled in Old Crow Flats and corresponding tree-ring chronology 733 information.

\begin{tabular}{|c|c|c|c|c|c|c|c|c|}
\hline $\begin{array}{l}\text { Site } \\
\text { code }\end{array}$ & $\begin{array}{l}\text { Lat. } \\
\left({ }^{\circ} \mathrm{N}\right)\end{array}$ & $\begin{array}{l}\text { Long. } \\
\left({ }^{\circ} \mathrm{W}\right)\end{array}$ & $\begin{array}{c}\text { Elev. } \\
(\mathrm{m})\end{array}$ & $\begin{array}{c}\text { No. series/ } \\
\text { trees }\end{array}$ & $\begin{array}{l}\text { First year } \\
\geq 1 \text { series }\end{array}$ & $\begin{array}{l}\text { First year } \\
\geq 4 \text { series }\end{array}$ & $\begin{array}{l}\text { Last } \\
\text { year }\end{array}$ & $\begin{array}{l}\text { Mean series } \\
\text { length (yrs) }\end{array}$ \\
\hline DP21 & 67.53 & 139.93 & 251 & $67 / 35$ & 1657 & 1727 & 2007 & 199.7 \\
\hline DP23 & 67.50 & 139.96 & 249 & $46 / 24$ & 1711 & 1716 & 2007 & 216.1 \\
\hline DP24 & 67.51 & 139.96 & 249 & $42 / 22$ & 1735 & 1746 & 2006 & 208.7 \\
\hline DP25 & 67.52 & 139.99 & 251 & $43 / 22$ & 1759 & 1778 & 2006 & 163.7 \\
\hline DP26 & 67.52 & 140.02 & 243 & $36 / 20$ & 1728 & 1739 & 2006 & 200.5 \\
\hline DP27 & 67.50 & 140.06 & 243 & $57 / 29$ & 1608 & 1738 & 2007 & 150.0 \\
\hline DP30 & 67.48 & 140.33 & 244 & $71 / 36$ & 1552 & 1555 & 2007 & 247.2 \\
\hline DP31 & 67.48 & 140.26 & 245 & $80 / 41$ & 1617 & 1620 & 2007 & 240.6 \\
\hline JC1 & 67.95 & 139.14 & 286 & $73 / 37$ & 1744 & 1808 & 2007 & 157.0 \\
\hline $\mathrm{OC} 2$ & 67.59 & 139.75 & 258 & $67 / 35$ & 1691 & 1742 & 2007 & 149.7 \\
\hline OC $9_{\mathrm{a}}$ & 67.70 & 139.81 & 267 & $54 / 27$ & 1618 & 1620 & 1846 & 183.8 \\
\hline $\mathrm{OC}_{\mathrm{b}}$ & 67.70 & 139.81 & 267 & $50 / 26$ & 1874 & 1881 & 2007 & 109.2 \\
\hline $\mathrm{OC} 10$ & 67.72 & 139.82 & 259 & $61 / 32$ & 1719 & 1727 & 2006 & 111.7 \\
\hline OC50 & 68.13 & 139.93 & 282 & $45 / 25$ & 1668 & 1768 & 2007 & 184.8 \\
\hline OC51 & 68.07 & 139.78 & 272 & $84 / 43$ & 1680 & 1714 & 2007 & 186.6 \\
\hline OC52 & 68.05 & 139.59 & 269 & $59 / 31$ & 1749 & 1753 & 2007 & 158.9 \\
\hline OC53 & 67.86 & 139.79 & 265 & $82 / 44$ & 1648 & 1649 & 2007 & 189.3 \\
\hline OC54 & 68.22 & 140.09 & 292 & $42 / 21$ & 1615 & 1627 & 2007 & 140.3 \\
\hline PC17 & 67.55 & 139.41 & 251 & $94 / 49$ & 1803 & 1811 & 2006 & 159.2 \\
\hline PC18 & 67.53 & 139.32 & 251 & $60 / 33$ & 1686 & 1711 & 2006 & 203.4 \\
\hline SC1 & 67.76 & 140.52 & 647 & $56 / 29$ & 1537 & 1553 & 2007 & 214.4 \\
\hline TH1 & 68.33 & 140.75 & 339 & $97 / 50$ & 1650 & 1661 & 2007 & 225.4 \\
\hline TM1 & 68.34 & 139.72 & 315 & $94 / 48$ & 1631 & 1648 & 2007 & 223.6 \\
\hline TM2 & 68.17 & 139.78 & 305 & $77 / 41$ & 1522 & 1547 & 2007 & 217.4 \\
\hline
\end{tabular}

N.B. $-\mathrm{OC} 9_{\mathrm{a}}$ and $\mathrm{OC} 9 \mathrm{~b}$ belong to the same site, but do not overlap because of a stand replacing

735 fire that occurred just prior to circa A.D. 1850; OC9 a represents a population of trees that died 736 before or during the fire and OC9b represents the post-burn population. 
Table 2. Correlations between the 23 Old Crow Flats site chronologies and previous-year June/July maximum temperatures (left) and growth-year June/July minimum temperatures (right) (see SI-Table 1 for May-August correlations); only correlations significant at $\mathrm{p} \leq 0.05$ (twotailed) are presented; sites are classed as Group 1/Group 2 if negatively/positively correlated with June/July temperatures.

\begin{tabular}{|c|c|c|c|c|}
\hline & \multicolumn{2}{|c|}{$\begin{array}{l}\text { Previous year }(\mathrm{t}-1) \\
\text { max. temperatures }\end{array}$} & \multicolumn{2}{|c|}{$\begin{array}{l}\text { Growth year }(\mathrm{t}) \\
\text { min. temperatures }\end{array}$} \\
\hline & June & July & June & July \\
\hline \multicolumn{5}{|l|}{ Mixed } \\
\hline DP21 & - & -0.29 & 0.31 & - \\
\hline \multicolumn{5}{|l|}{ Group 1} \\
\hline DP27 & -0.45 & -0.58 & -0.28 & -0.41 \\
\hline DP30 & -0.28 & -0.43 & - & - \\
\hline OC9 & -0.50 & -0.54 & -0.42 & -0.41 \\
\hline OC10 & -0.24 & -0.48 & - & - \\
\hline OC50 & -0.42 & -0.40 & - & - \\
\hline OC52 & -0.41 & -0.57 & - & -0.25 \\
\hline OC53 & -0.25 & -0.48 & - & - \\
\hline OC54 & -0.41 & -0.58 & -0.31 & -0.35 \\
\hline PC18 & -0.35 & -0.54 & - & -0.23 \\
\hline TM1 & - & -0.41 & - & - \\
\hline TM2 & -0.41 & -0.62 & - & - \\
\hline \multicolumn{5}{|l|}{ Group 2} \\
\hline DP23 & - & - & 0.41 & - \\
\hline DP24 & 0.35 & - & 0.54 & 0.43 \\
\hline DP25 & 0.35 & 0.24 & 0.54 & 0.48 \\
\hline DP26 & 0.33 & - & 0.52 & 0.38 \\
\hline DP31 & - & - & 0.48 & 0.27 \\
\hline $\mathrm{JC} 1$ & - & - & 0.39 & - \\
\hline OC2 & - & - & 0.44 & 0.26 \\
\hline OC51 & 0.24 & - & 0.57 & 0.45 \\
\hline PC17 & 0.38 & 0.25 & 0.54 & 0.41 \\
\hline SC1 & 0.34 & - & 0.53 & 0.43 \\
\hline TH1 & 0.24 & - & 0.58 & 0.42 \\
\hline \multicolumn{5}{|l|}{$\begin{array}{c}\text { Regional } \\
\text { means }\end{array}$} \\
\hline Group 1 & -0.42 & -0.61 & - & -0.24 \\
\hline Group 2 & 0.28 & - & 0.57 & 0.40 \\
\hline
\end{tabular}


Table 3. List of 300+ year white spruce ring-width chronologies from upper NWNA $\left(65-70^{\circ} \mathrm{N}\right.$, $115-170^{\circ} \mathrm{W}$ ) that we compared to the mean Group 1 (G1)/Group 2 (G2) chronologies from Old Crow Flats. Correlations with G1/G2 were calculated for all years of overlapping data for the periods 1850-1930 and 1930-2003; only positive correlations significant at $\mathrm{p} \leq 0.01$ (one-tailed) are provided. Site \# corresponds to the map of NWNA sites (Figure 5). Mean chronologies for each NWNA site were calculated from raw ring-width data using signal-free standardisation as outlined in the Methods section. All ring-width files were downloaded from ITRDB (accessed Sept. 2009) unless stated otherwise.

\begin{tabular}{|c|c|c|c|c|c|c|}
\hline \multirow[t]{3}{*}{ Site \# } & \multirow{3}{*}{ Site name, ITRDB code } & \multirow{3}{*}{$\begin{array}{l}\text { Temporal } \\
\text { coverage }\end{array}$} & \multicolumn{4}{|c|}{ Correlation with G1/G2 } \\
\hline & & & \multicolumn{2}{|c|}{$1850-1930$} & \multicolumn{2}{|c|}{$1930-2003$} \\
\hline & & & G1 & $\mathrm{G} 2$ & G1 & $\mathrm{G} 2$ \\
\hline 01 & Almond Butter Lower, AK057 & $1607-2002$ & 0.26 & 0.32 & - & 0.58 \\
\hline 02 & Almond Butter Upper, AK058 & $1406-2002$ & - & - & - & - \\
\hline 03 & Alpine View, AK059 & $1542-2002$ & - & - & - & - \\
\hline 04 & Burnt Over, AK060 & $1621-2002$ & 0.27 & 0.29 & - & 0.46 \\
\hline 05 & Bye Rosanne, AK061 & $1575-2002$ & - & - & 0.47 & - \\
\hline 06 & Death Valley, AK062 & $1358-2002$ & - & - & - & - \\
\hline 07 & Echo Slope, AK063 & $1590-2002$ & - & - & - & - \\
\hline 08 & Frost Valley, AK064 & $1611-2002$ & - & - & 0.31 & - \\
\hline 09 & Gordon's Cat, (AK065 & $1400-2002$ & - & - & - & - \\
\hline 10 & Hey Bear, AK066 & $1533-2002$ & - & - & - & - \\
\hline 11 & Hey Bear Upper, AK067 & $1383-2002$ & - & - & - & - \\
\hline 12 & Mt. Mole, AK068 & $1550-2002$ & - & - & - & - \\
\hline 13 & Windy Ridge, AK070 & $1556-2002$ & - & - & - & - \\
\hline 14 & ${ }^{\mathrm{a}}$ Four-Twelve with Revisit, AK031 & $1515-1990$ & 0.55 & 0.51 & 0.63 & - \\
\hline 15 & ${ }^{\mathrm{b}}$ Kobuk/Noatak, AK046 & 978-1992 & - & - & 0.36 & 0.29 \\
\hline 16 & ${ }^{\mathrm{a}}$ Arrigetch, AK032 & $1585-1990$ & 0.41 & 0.39 & - & 0.50 \\
\hline 17 & Sheenjek River and Flats, AK033 & 1296-1979 & 0.41 & 0.37 & 0.51 & - \\
\hline 18 & ${ }^{\mathrm{c}}$ Firth River, AK047 & $1676-2002$ & 0.71 & 0.71 & - & - \\
\hline 19 & Spruce Creek, CANA029 & $1570-1977$ & 0.34 & 0.26 & 0.48 & - \\
\hline 20 & ${ }^{\mathrm{d}}$ Richardson Mountain, CANA121 & 1547-1992 & 0.64 & 0.65 & 0.59 & - \\
\hline 21 & ${ }^{a}$ Twisted Tree Heartrot Hill, CANA157 & 1459-1999 & 0.65 & 0.66 & 0.69 & - \\
\hline 22 & ${ }^{\mathrm{e}} \mathrm{MDEC}$ Positive Responders & $1516-2003$ & 0.77 & 0.82 & - & 0.86 \\
\hline 23 & ${ }^{\mathrm{e}} \mathrm{MDEC}$ Negative Responders & $1501-2003$ & 0.72 & 0.73 & 0.82 & - \\
\hline 24 & ${ }^{\mathrm{f}}$ Campbell Dolomite Upland, CANA138 & 1060-1992 & 0.56 & 0.45 & 0.67 & - \\
\hline 25 & Mackenzie Mountains, CANA156 & $1509-1984$ & - & - & 0.69 & - \\
\hline 26 & Franklin Mountains, CANA154 & $1621-1984$ & 0.39 & 0.34 & - & 0.45 \\
\hline 27 & ${ }^{\mathrm{d}}$ Discovery Ridge, CANA117 & 1429-1991 & 0.35 & 0.26 & - & 0.63 \\
\hline 28 & ${ }^{\mathrm{a}}$ Coppermine River, CANA153 & $1046-2003$ & 0.53 & 0.59 & - & 0.29 \\
\hline
\end{tabular}

771

772

773

774

775

776

Data contributors by site \#: Church and Fritts (19); D’Arrigo, Mashig, Frank, Wilson, and Jacoby (01-13); Jacoby, D'Arrigo, and Buckley (14, 16-17, 21, 25-26, and 28); King and Graumlich (15); Pisaric (22-23); Szeicz and MacDonald (27); Szeicz, MacDonald, and Lundberg (20 and 24); Wilmking (18).

aUpdated versions of sites 14, 16, 21, and 28 (not yet available on ITRDB) were provided by R. D’Arrigo (pers. comm.). 
794

795

796

797

798

799

800

801

802

803

804

805

806

807

808

809

810

811

812

813

814

815

816

817

${ }^{b}$ Kobuk/Noatak is a regional $\left(24,000 \mathrm{~km}^{2}\right.$ area $)$ composite developed from hundreds of trees in the Kobuk and Noatak River basins. ${ }^{\mathrm{c} C}$ ross-dating verification using COFECHA indicated that two of the Firth River series (BRFR49 $\& 88$ ) should be adjusted -1 year. The possibility these series were misaligned was confirmed by M. Wilmking (pers. comm., Sept. 2010). Adjusting these series increased their correlation with the BRFR49/88 master chronologies from 0.03/0.11 to 0.40/0.41.

${ }^{\mathrm{d}}$ As per Szeicz and MacDonald (1995), we used only 200+/100+ year series for Discovery Ridge/Richardson Mountain.

${ }^{f}$ MDEC (Mackenzie Delta East Channel) represents several sites in the Mackenzie Delta whose individual series were pooled into 'positive- or negative-responder' chronologies (Pisaric et al. 2007). The Positive and Negative Responder chronologies used here are modified versions of the originals used by Pisaric et al. (2007); see SI-Note 2 for more details.

${ }^{\mathrm{f}}$ A subset (11 trees) of samples collected by Szeicz, MacDonald, and Lundberg from Campbell Dolomite Upland was developed into a separate 'Campbell Dolomite Upland B' chronology by F. Schweingruber and is available on the ITRDB. Here we only use the Szeicz, MacDonald, and Lundberg version because of its much larger sample depth.

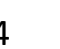

5

(1)

8

9

1


Table 4. NWNA chronologies that meet the following two similarity criteria: (1) correlates positively and significantly ( $\mathrm{p} \leq 0.01$ ) with both Group 1 and Group 2 from 1850-1930; and (2) correlates positively and significantly with only one of Group 1 or Group 2 from 1930-present. Chronologies that meet these criteria and are most closely associated Group 1/Group 2 during 1930-2003 are classed as NWNA 1/NWNA 2 chronologies.

\begin{tabular}{l}
\hline NWNA 1 chronologies \\
\hline Campbell Dolomite Upland \\
Four-Twelve with Revisit \\
MDEC Negative Responders \\
Richardson Mountain \\
Sheenjek River and Flats \\
Spruce Creek \\
Twisted Tree Heartrot Hill \\
\hline NWNA 2 chronologies \\
\hline Almond Butter Lower \\
Arrigetch \\
Burnt Over \\
Coppermine River \\
Discovery Ridge \\
Franklin Mountains \\
MDEC Positive Responders \\
\hline
\end{tabular}

Franklin Mountains

MDEC Positive Responders 
847 Table 5. Correlations between the mean NWNA 1/NWNA 2 chronologies and regional mean 848 monthly CRUTEM3v temperatures (Brohan et al. 2006; see SI-Note 3); correlations for May849 August of the prior and current growth years are provided for three periods: 1900-2003, 1900850 1950, and 1951-2003; all correlations are significant at $\mathrm{p} \leq 0.05$ (two-tailed); underlined 851 coefficients are significant at $\mathrm{p} \leq 0.01$.

\begin{tabular}{cl|ccc|ccc}
\hline & & \multicolumn{3}{c|}{ NWNA1 } & \multicolumn{3}{c}{ NWNA2 } \\
\cline { 3 - 8 } & & $1900-$ & $1900-$ & $1951-$ & $1900-$ & $1900-$ & $1951-$ \\
& & 2003 & 1950 & 2003 & 2003 & 1950 & 2003 \\
\hline Year & May & - & - & - & $\underline{0.34}$ & - & - \\
t-1 & Jun & - & - & - & $\underline{0.41}$ & - & $\underline{0.40}$ \\
& Jul & $\underline{-0.36}$ & - & $\underline{-0.40}$ & $\underline{0.29}$ & - & - \\
& Aug & - & - & - & 0.21 & - & - \\
\hline Year & May & -0.20 & - & $\underline{-0.30}$ & 0.20 & - & - \\
t & Jun & - & $\underline{0.53}$ & - & $\underline{0.54}$ & $\underline{0.47}$ & $\underline{0.46}$ \\
& Jul & - & $\underline{0.39}$ & - & $\underline{0.54}$ & $\underline{0.41}$ & $\underline{0.36}$ \\
& Aug & - & 0.20 & - & 0.21 & - & - \\
\hline
\end{tabular}

852

853

854

855

856

857

858

859

860

861

862

863

864

865 
866 Figure 1 - (a) White spruce sites sampled in Old Crow Flats (site codes indicated, see Table 1).

867 Major lakes and channels are shaded grey. (b) Climate stations at Fairbanks (FAI), Fort Yukon

868 (FTY), Inuvik (INU), Aklavik (AKL), and Fort McPherson (FTM). (c) Large-scale context of

869 Old Crow Flats. Boreal treeline was delineated from the Circumpolar Arctic Vegetation Map

870 dataset (Walker et al. 2005).

871

872 Figure 2 - Monthly normals (1971-2000) for minimum, mean, and maximum temperatures

873 (lines), and total precipitation (bars) at Old Crow (www.climate.weatheroffice.ec.gc.ca).

874

875 Figure 3 - (a/b) Group 1/Group 2 site chronologies (grey lines); all site chronologies are defined 876 by no less than 4 series ( $\geq 2$ trees). The mean Group 1/Group 2 chronologies (black lines) were

877 calculated using a robust bi-weight mean for all years defined by 2 or more site chronologies.

878 Sample depth curves are indicated above each plot. (c) A comparison of the mean Group 1

879 (1555-2007) and Group 2 (1620-2007) chronologies. The running 51-year correlation (above

880 plot) indicates coherence between the chronologies (dashed line is $\mathrm{p} \leq 0.05$ level). (d) High-pass

881 filtered (40-year cubic smoothing spline with a 50\% frequency cut-off; Cook and Peters 1981)

882 comparison of the mean Group 1 and Group 2 chronologies; the high-pass series were smoothed 883 with a 3-year cubic-smoothing spline for ease of comparison. 
885 Figure 4 - Comparisons between mean Group 1/Group 2 (black lines) and previous-year July

886 maximum/growth-year June minimum temperatures (grey lines); correlations are significant at $\mathrm{p}$

$887 \leq 0.001$.

888

889 Figure 5 - Locations of all NWNA site chronologies compared to the mean Group 1/Group 2

890 chronologies (site numbers indicated, see Table 3).

891

892 Figure 6 - Same as Figure 3, but for NWNA 1/NWNA 2 chronologies (Table 4; including the 893 mean Group 1/Group 2 chronologies).

895 Figure 7 - Comparison between the mean NWNA 1/NWNA 2 (dotted/grey line) chronologies 896 and a regional composite of June/July temperatures for NWNA (solid black line; see SI-Note 3).

898 Figure 8 - (a) Northern Hemisphere (NH) temperature reconstructions by Jones et al. (1998), 899 Briffa (2000), Esper et al. (2002), D’Arrigo et al. (2006), Wahl and Ammann (2007), and Wilson 900 et al. (2007) (grey lines); mean reconstruction (black line). The reconstructions were expressed 901 as z-scores relative to the common period of overlap (1750-1980). (b) Comparison of the mean 902 NH temperature reconstruction (thick black line; smoothed with 15-year cubic smoothing spline, 903 Cook and Peters 1981) against the mean NWNA 1/NWNA 2 chronologies (dotted/grey line).

904 The mean NWNA chronologies are defined by a minimum of 2 site chronologies. 


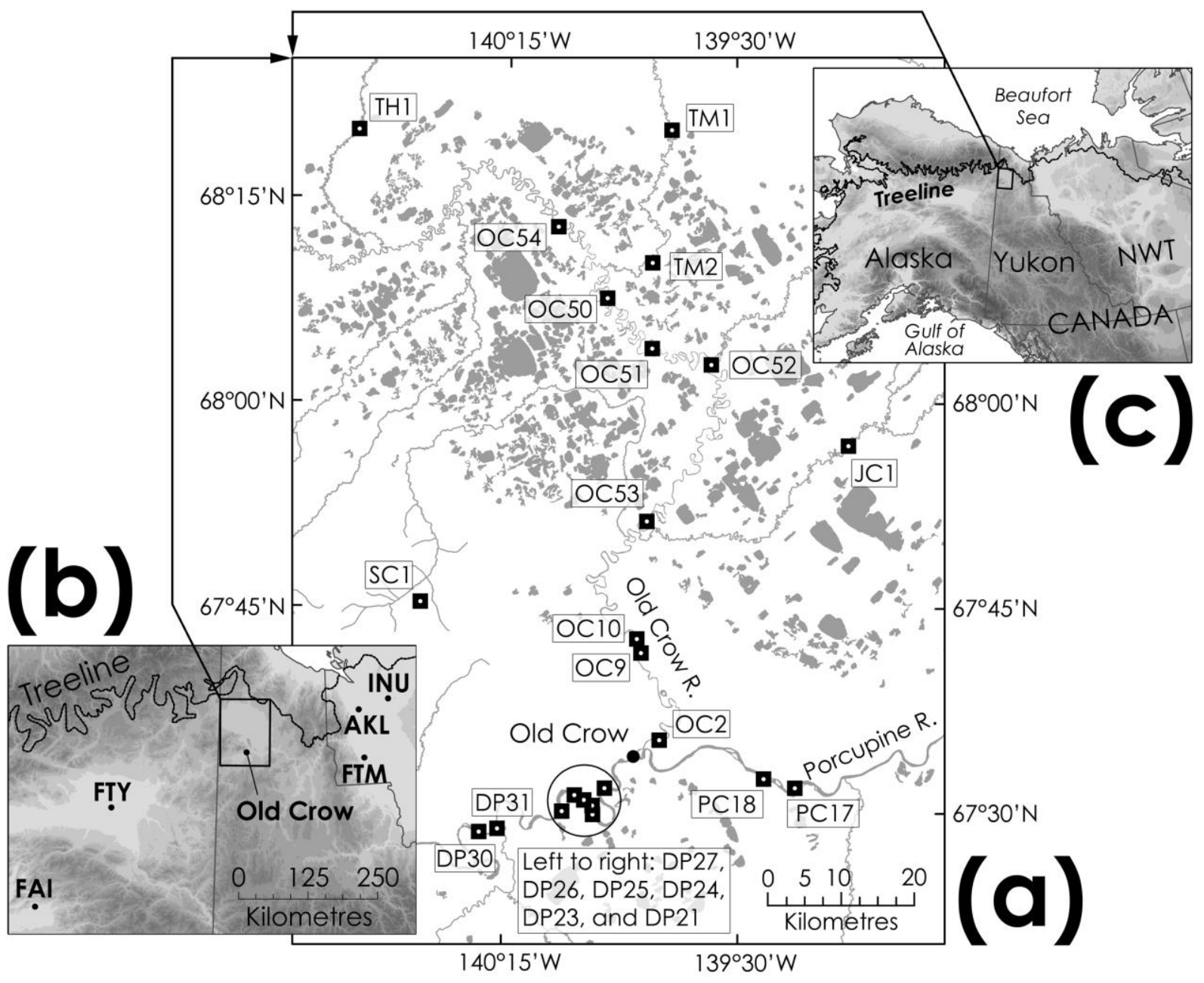

906

Fig. 1

907

908

909

910

911 


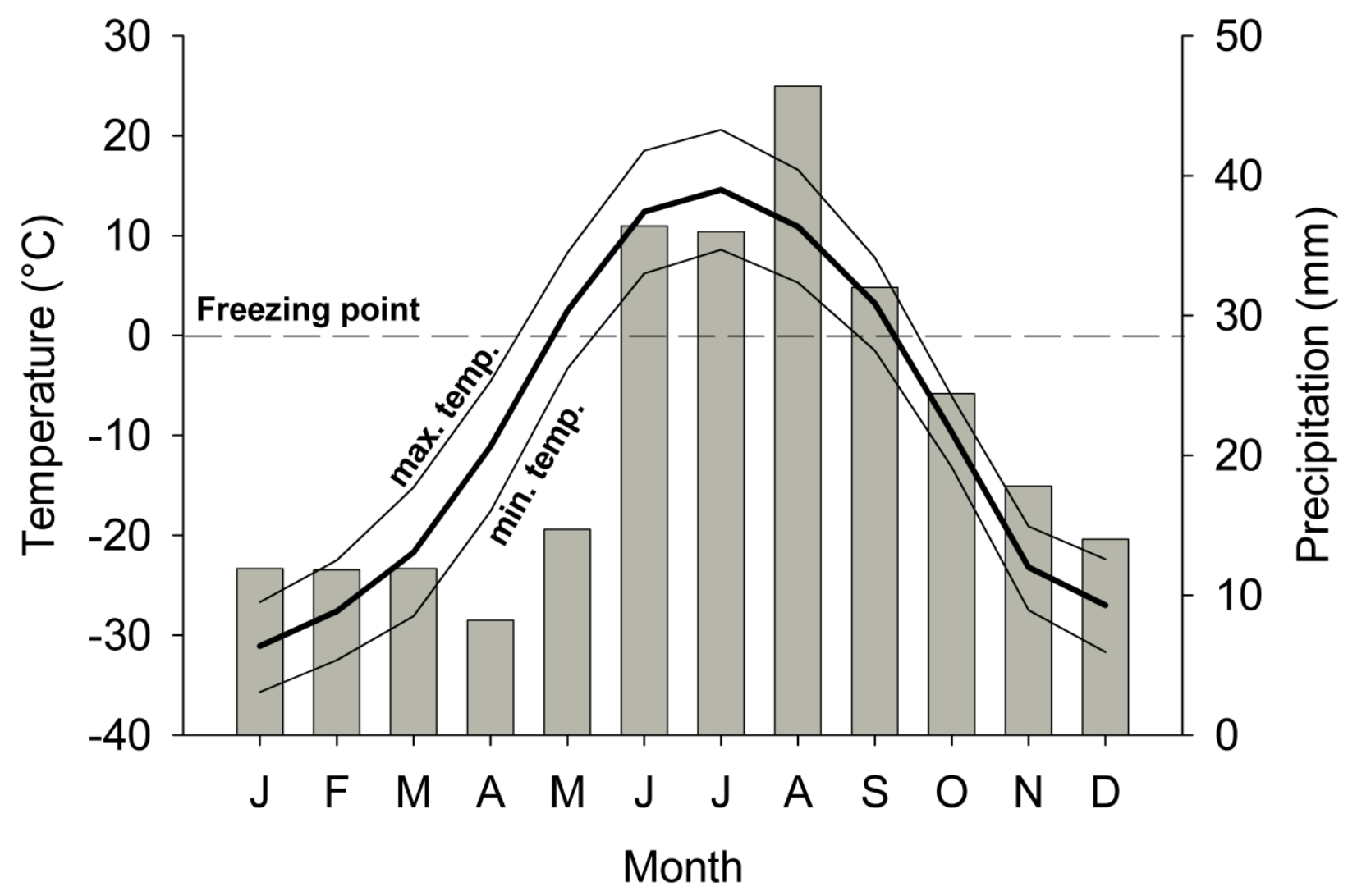

$913 \quad$ Fig. 2

914

915

916

917

918

919 


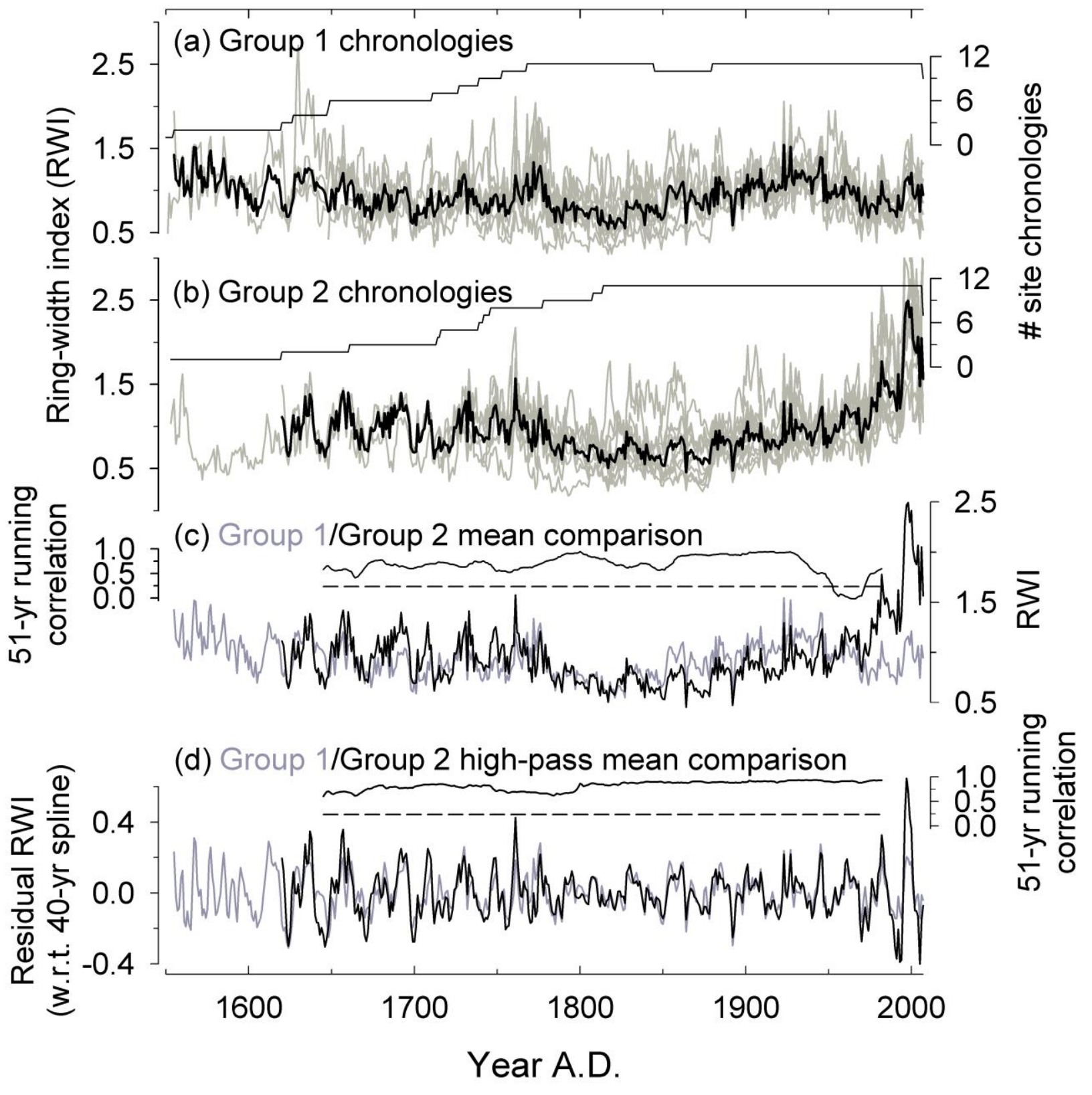

921 Fig. 3

922

923

924 


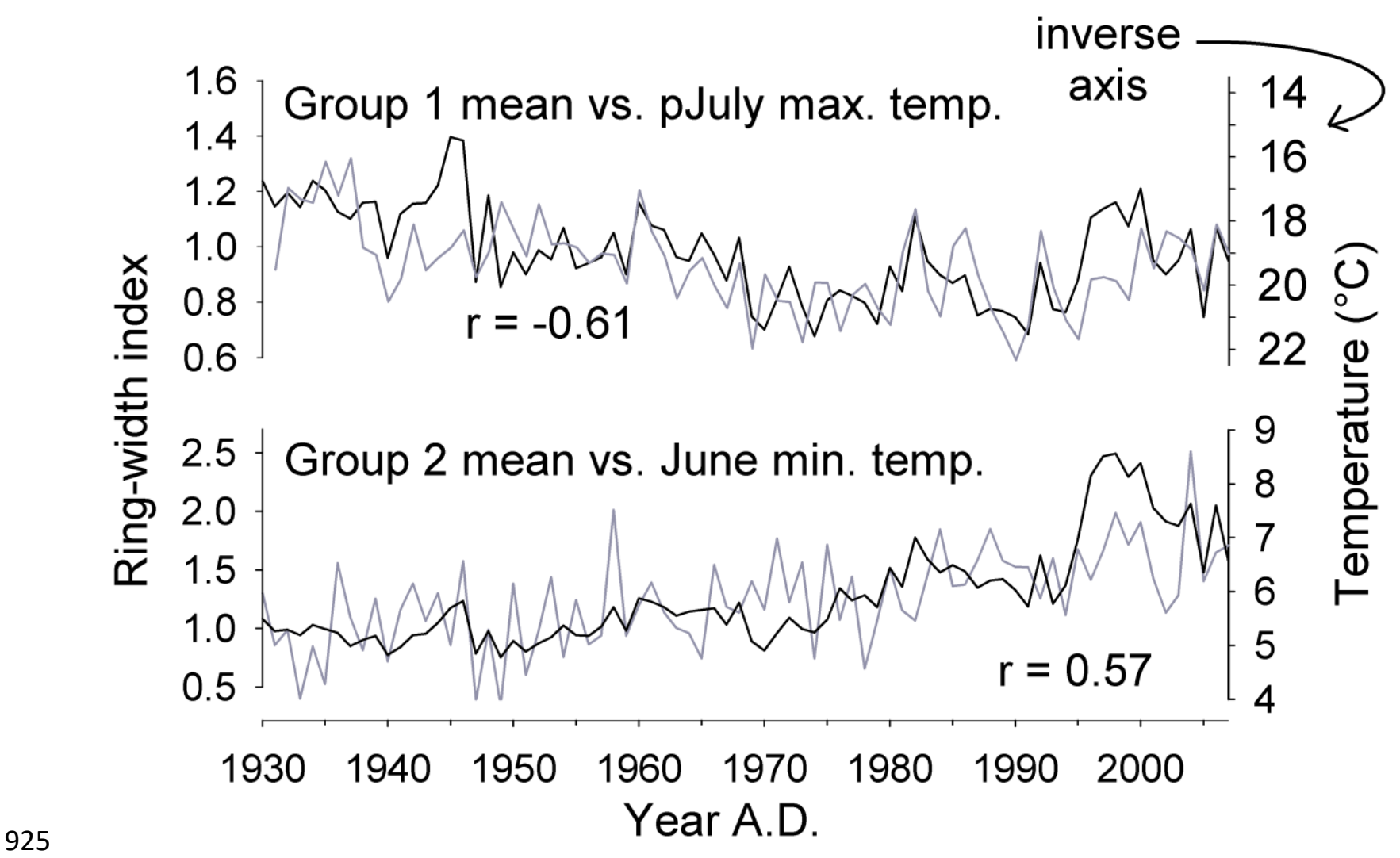

$926 \quad$ Fig. 4

927

928

929

930

931

932

933 


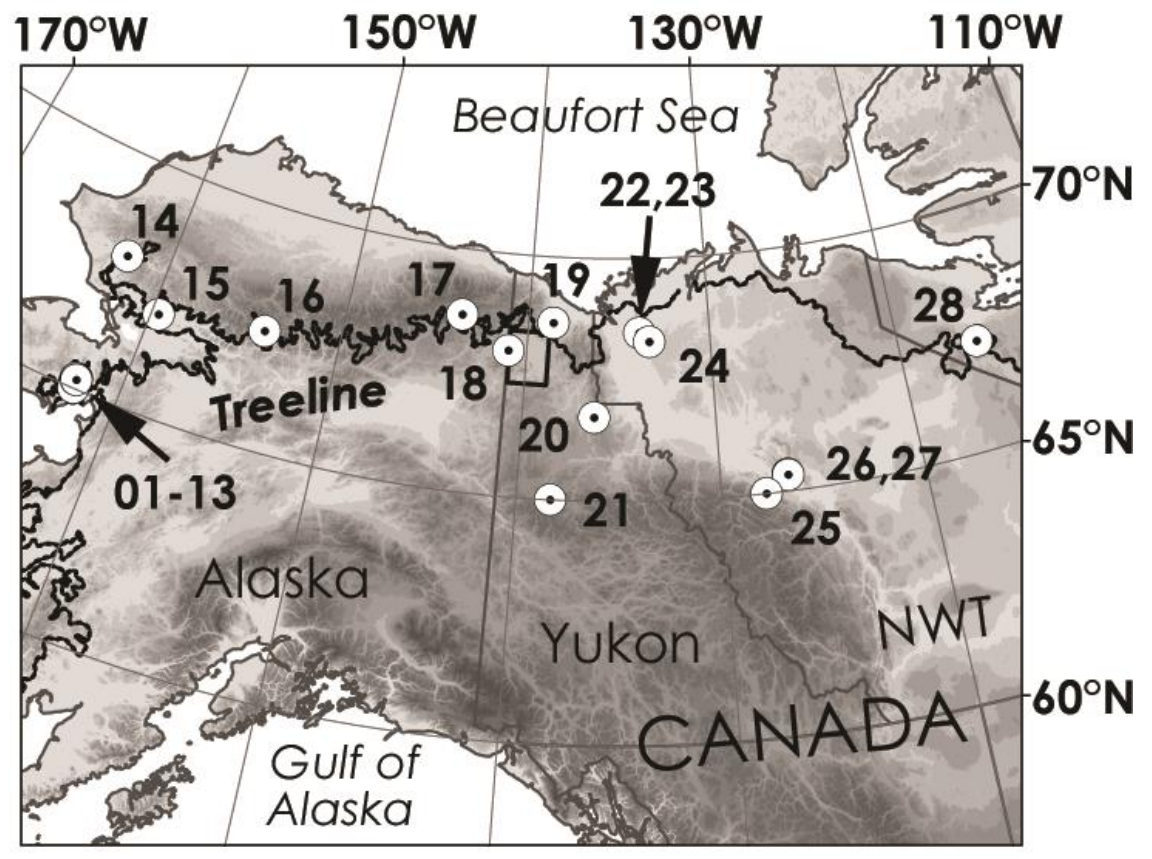

935 Fig. 5

936

937

938

939

940

941

942

943 


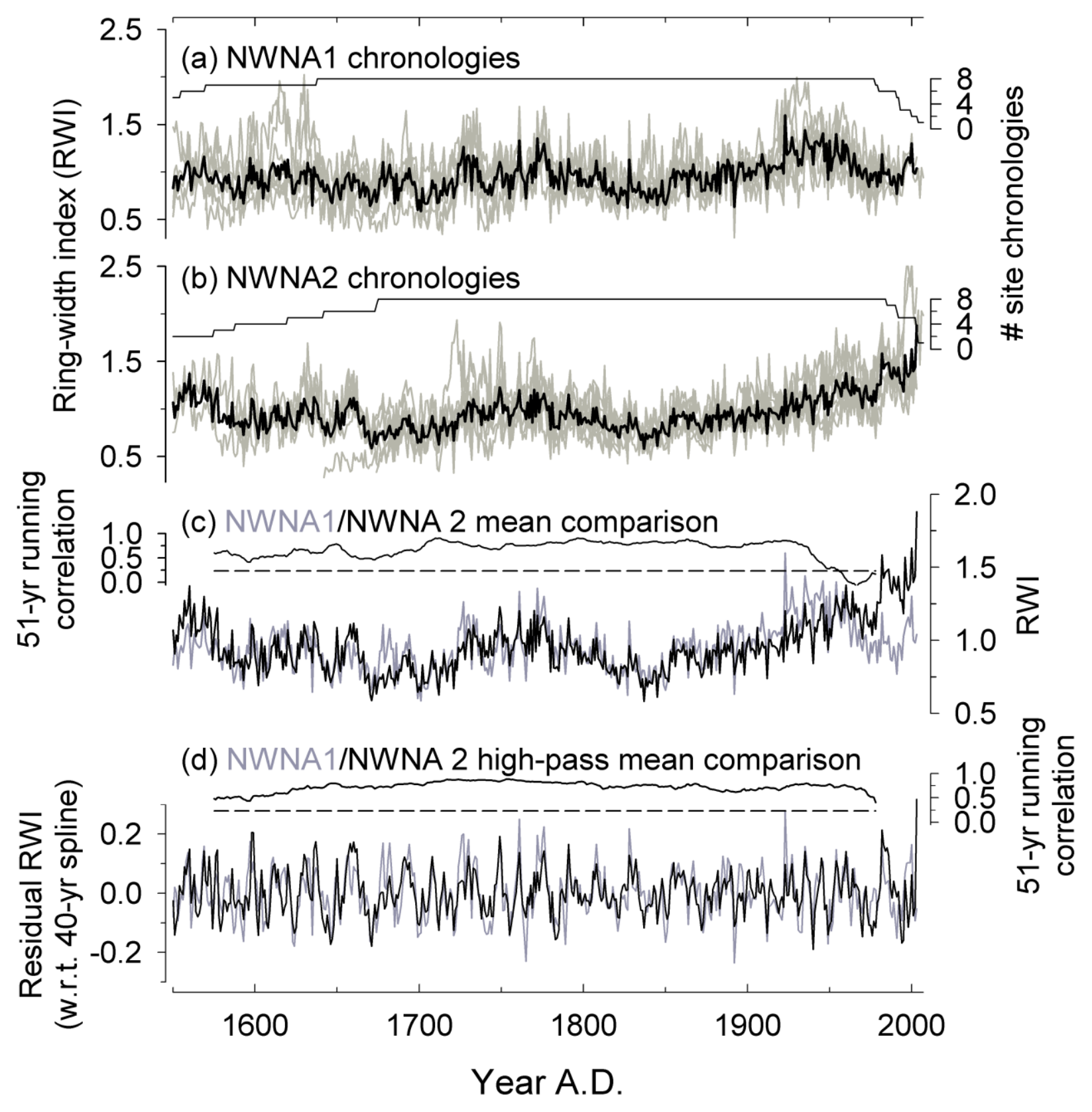

945

Fig. 6

946

947 


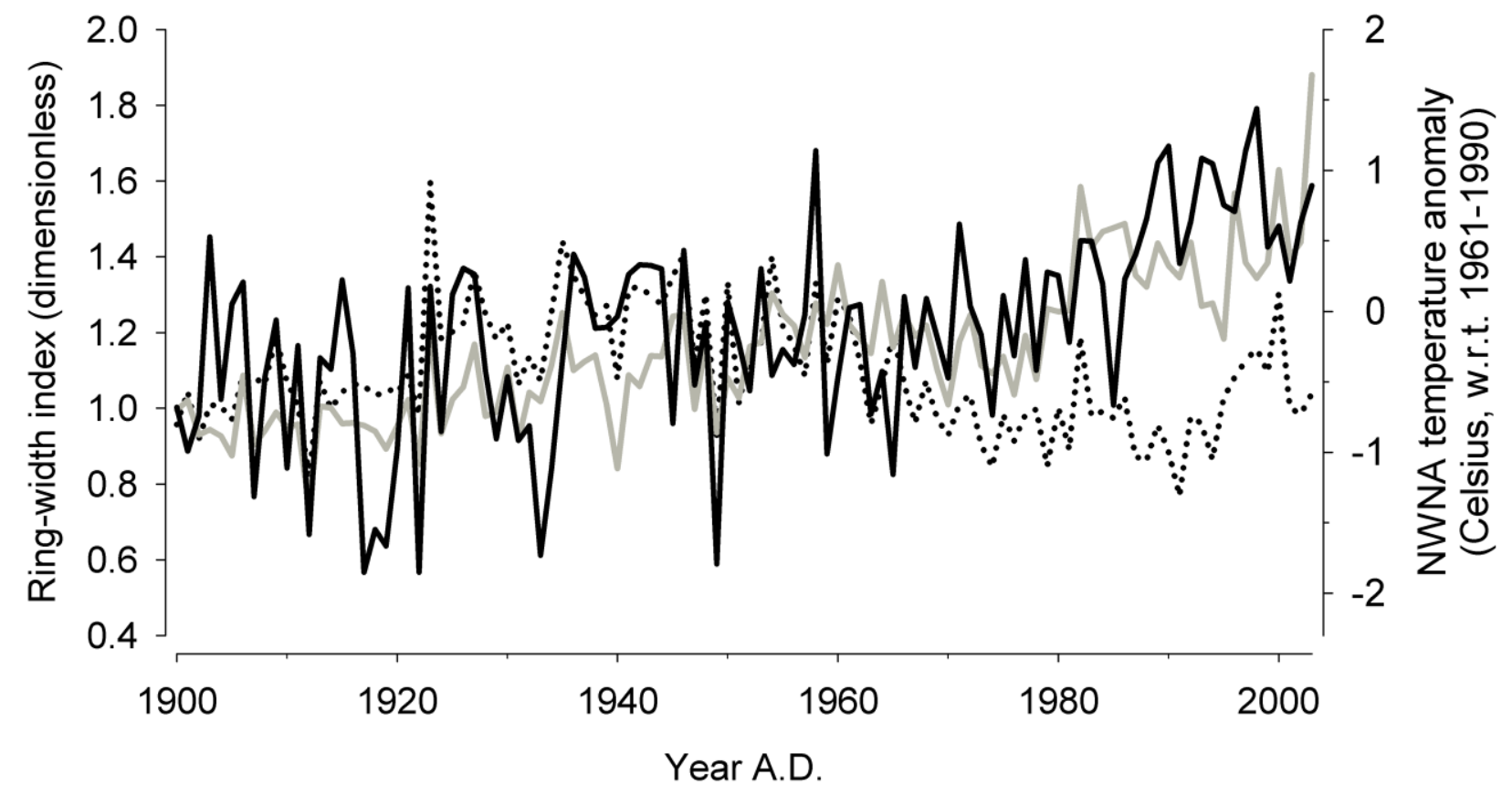

$950 \quad$ Fig. 7

951

952

953

954

955

956

957

958

959 


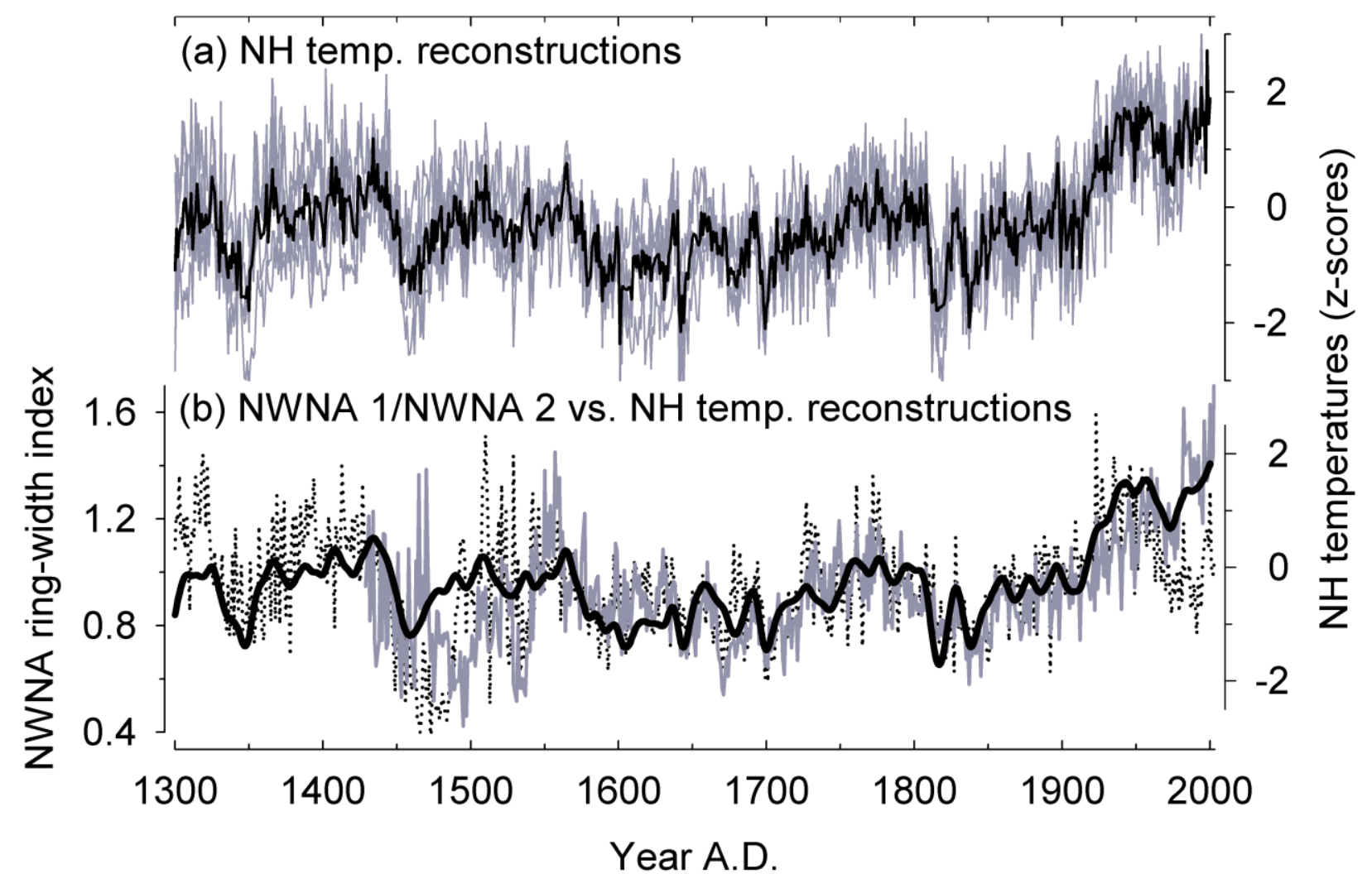

961 Fig. 8 


\section{Supporting Information}
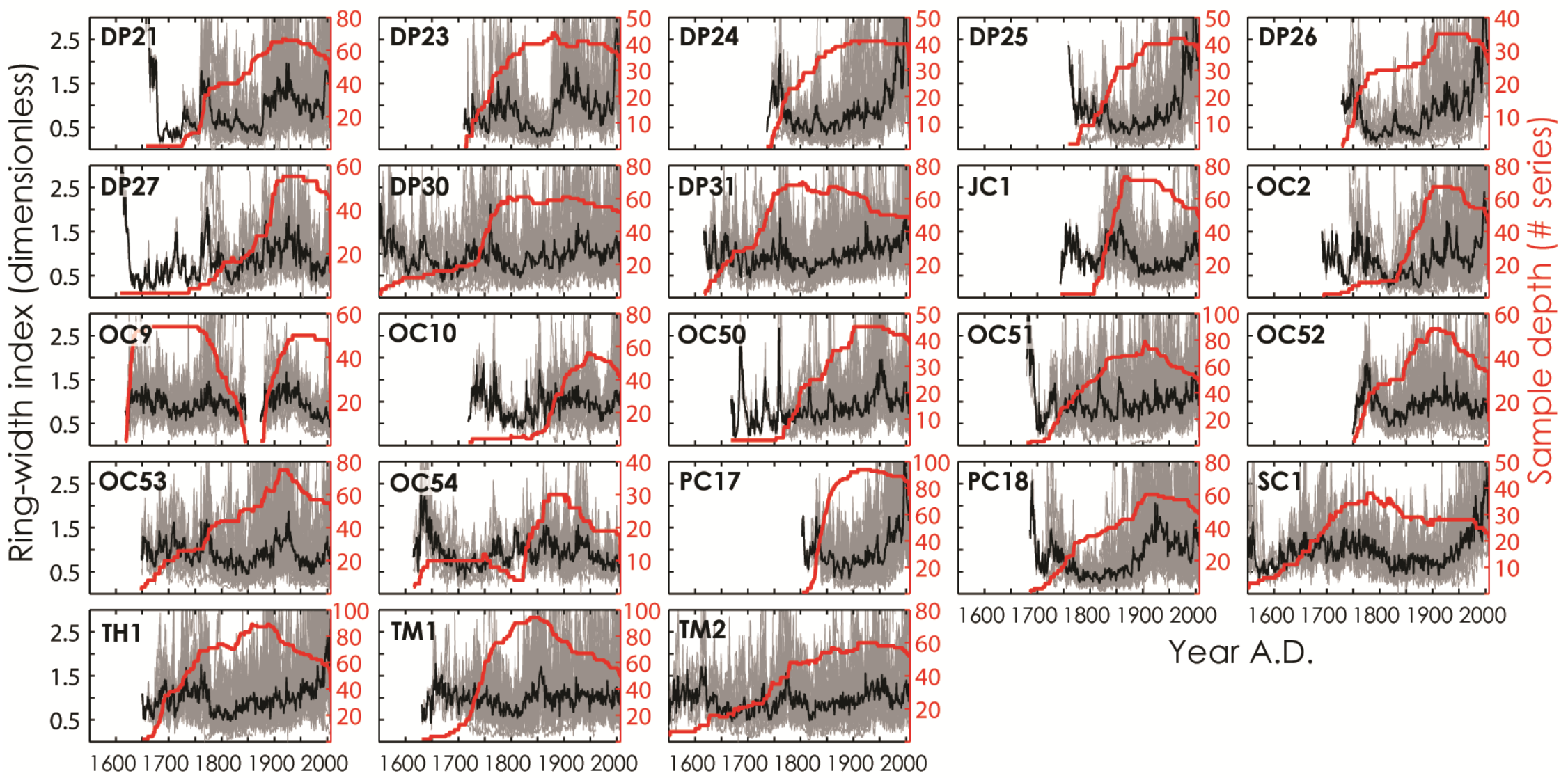

Year A.D.

SI-Figure 1. Standardized ring-width indices (grey lines) and mean site chronologies (black lines) for each site in Old Crow Flats

based on signal-free standardisation (Melvin and Briffa 2008) using conservative 'negative exponential' or 'negative-to-zero slope

linear’ curve fits (Fritts et al. 1969). Sample depth (red lines) indicates the number of series defining the mean chronology. The mean chronologies were calculated with a robust bi-weight mean (Cook 1985); more details on each chronology are provided in Table 1. 


\section{Supporting Information}
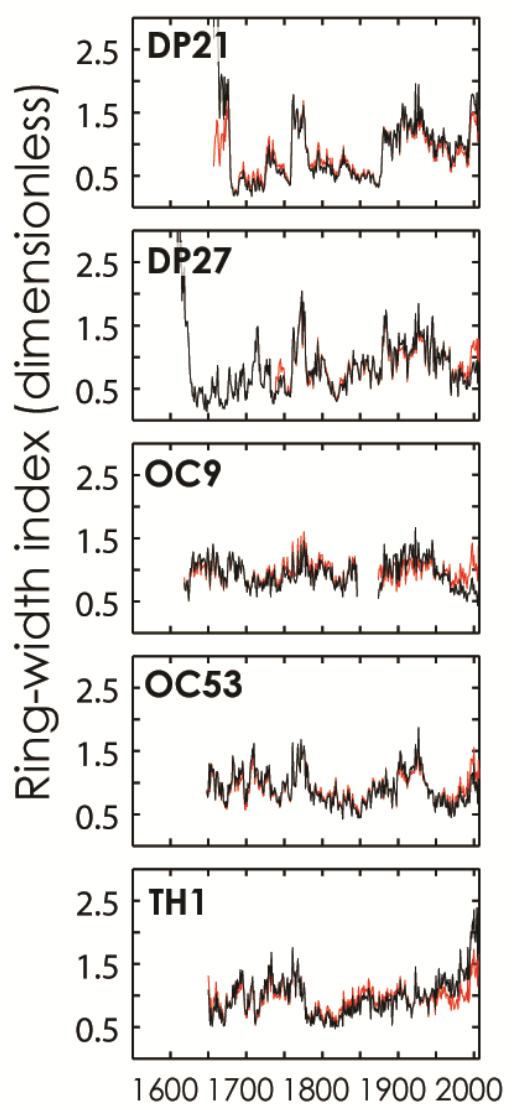
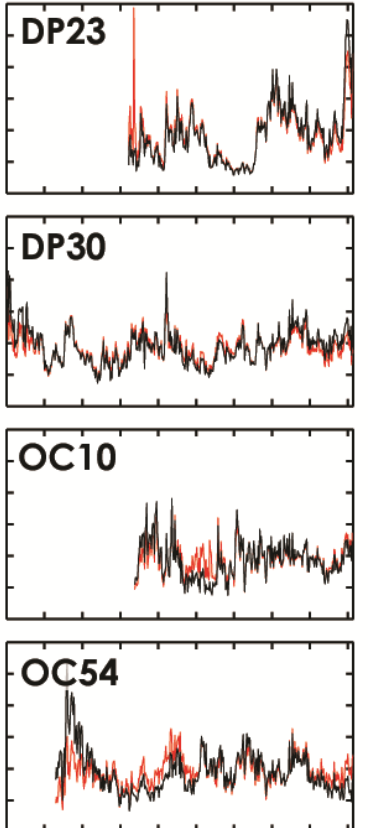

TM1

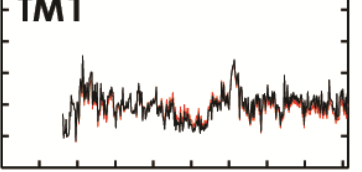

16001700180019002000
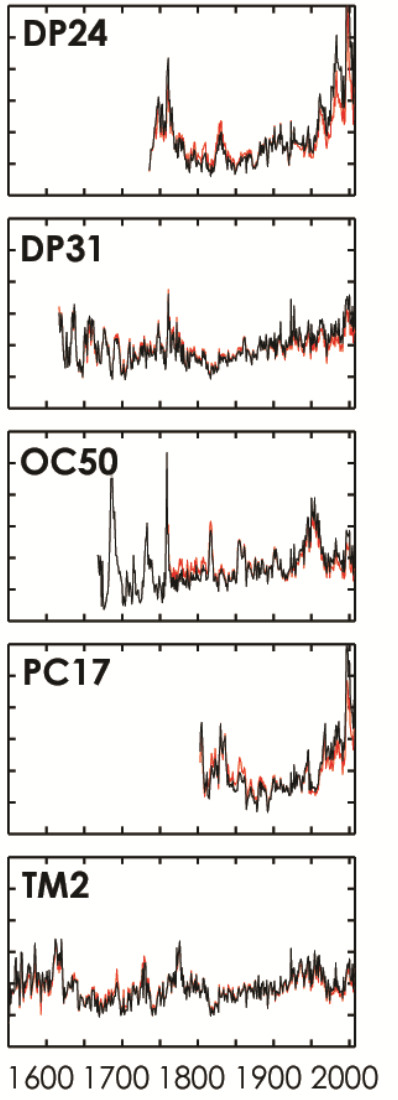
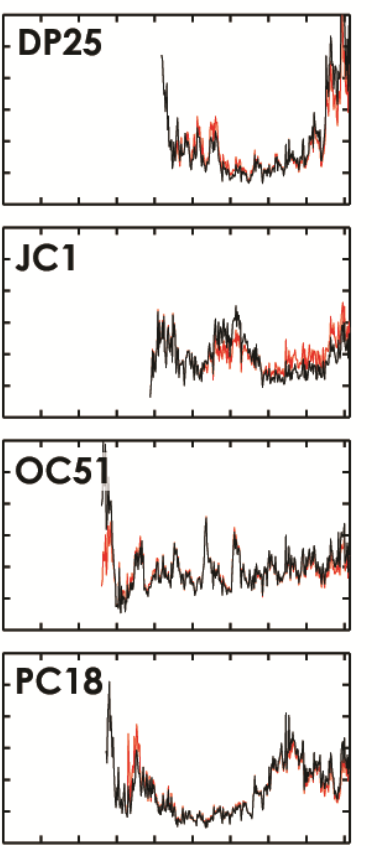

16001700180019002000
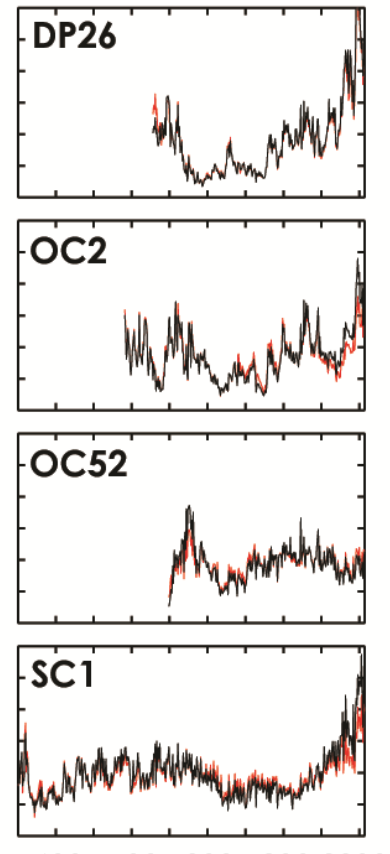

Year A.D.

SI-Figure 2. A comparison of each mean site chronology produced using 'signal-free' (black lines) and non-signal-free (red lines) methods. Inter-series differences can be considered the result of 'trend distortion' (Melvin and Briffa 2008). Due to differences in non-age-related growth (i.e., forced by climate, disturbance, etc.) between sites, trend distortion effects are more pronounced in some chronologies (e.g., JC1, OC9, OC54, SC1, and TH1) than in others (e.g., DP26, OC50, OC52, TM1, and TM2). 


\section{Supporting Information}

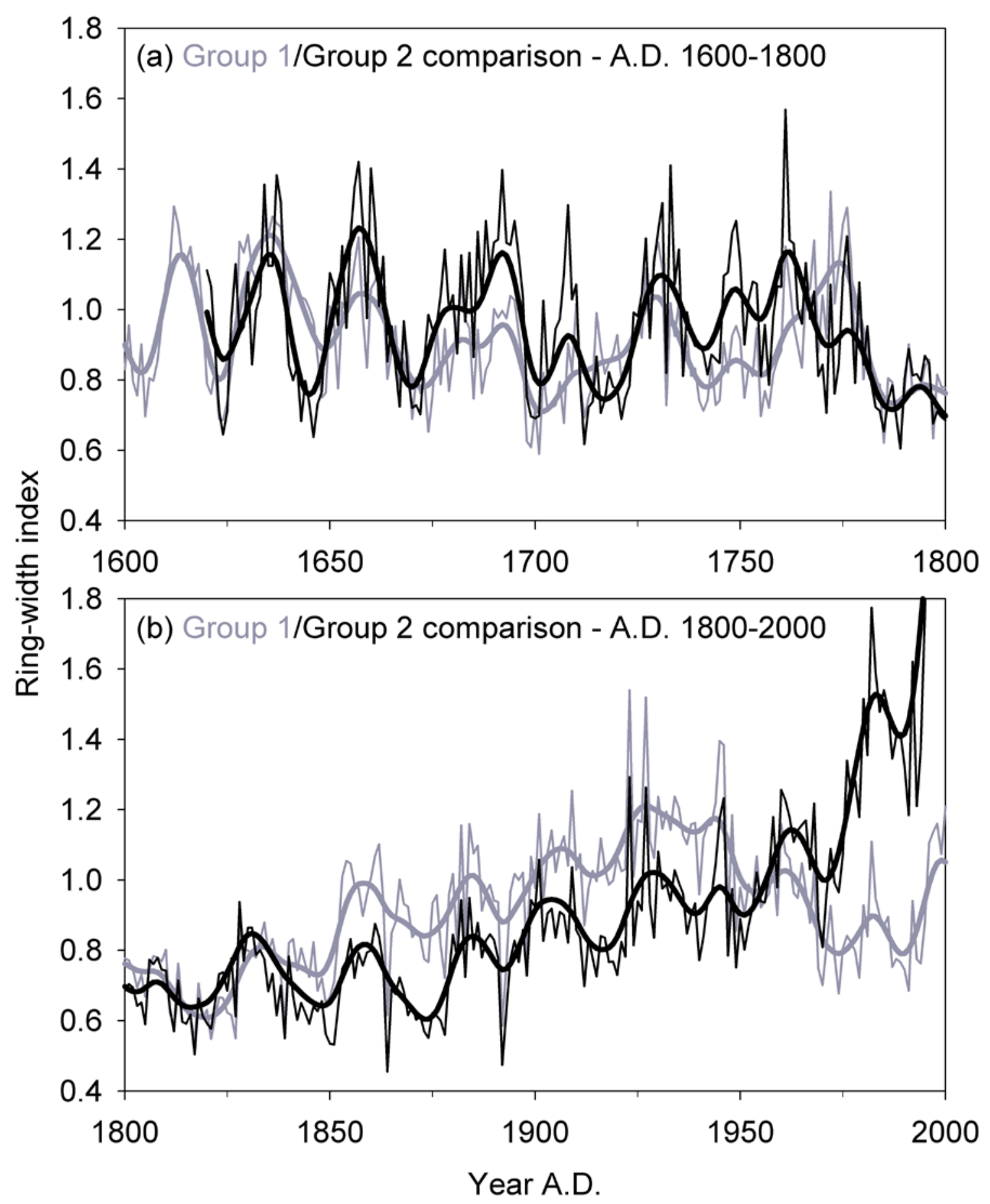

SI-Figure 3. Magnified comparison of the mean Group 1 and Group 2 chronologies during (a) 1600-1800 and (b) 1800-2000. Smoothed chronologies were calculated using a 15-year cubic smoothing spline with a 50\% frequency cut-off (Cook and Peters 1981). 


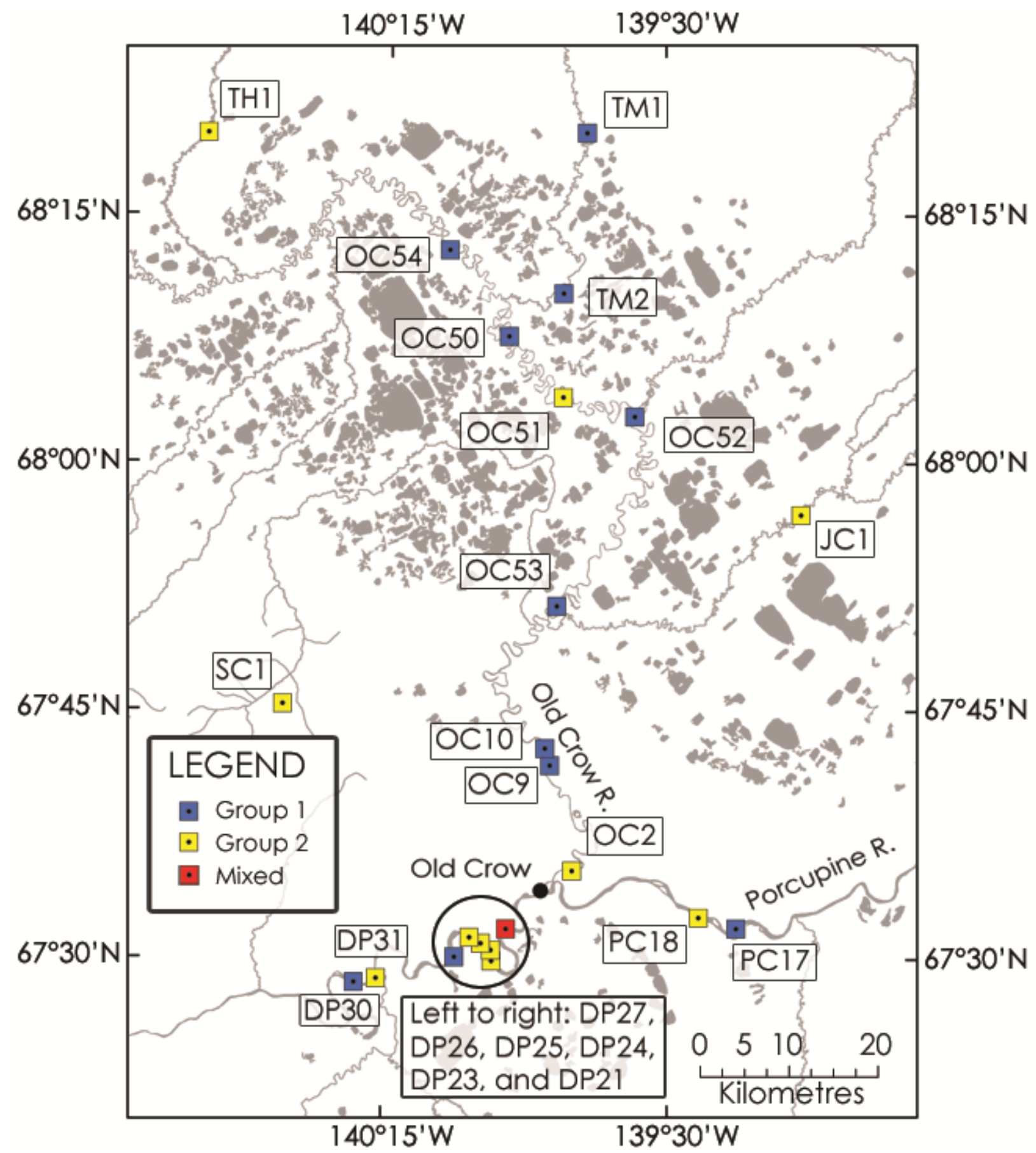

SI-Figure 4. Old Crow Flats sites: Group 1 (negative temperature response), Group 2 (positive temperature response), and Mixed (mixed negative/positive temperature response). 


\section{Supporting Information}

SI-Table 1. Correlations between the 23 Old Crow Flats 'signal-free' site chronologies and minimum/maximum temperatures from

May-August of the growth year $(\mathrm{t})$ and previous growth year $(\mathrm{t}-1)$; only correlations significant at $\mathrm{p} \leq 0.05$ (two-tailed) are presented.

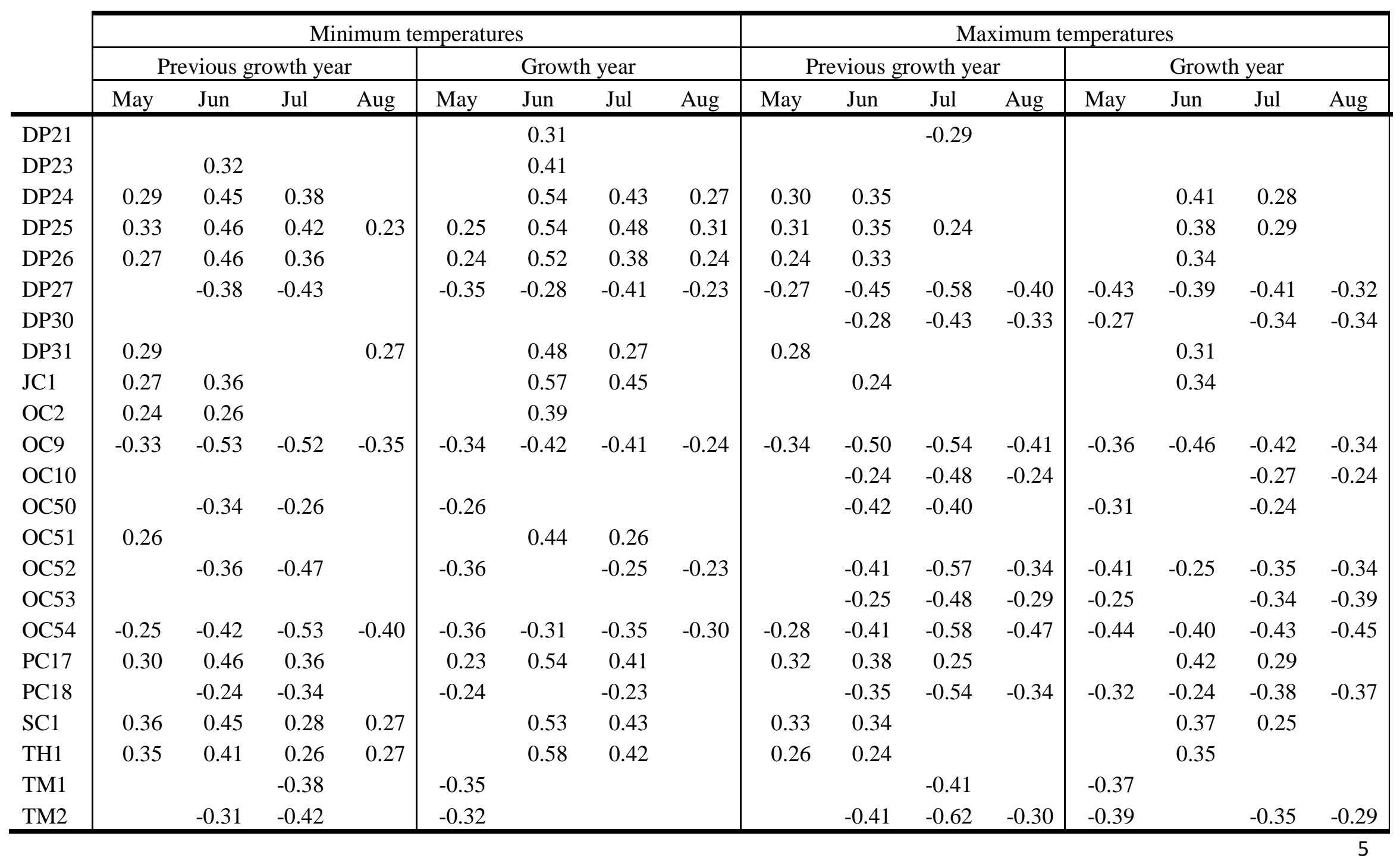




\section{Supporting Information}

SI-Note 1. A running 2-sample t-test was used to test the null hypothesis that the Group 1 and 2 site chronologies are derived from the same normal distribution with equal means and variance $(\mathrm{p} \leq 0.05)$. The null hypothesis was tested for each year that both groups contained four or more site chronologies. The t-test result was calculated using the 'ttest2' function (Statistics Toolbox) in Matlab 7.4.

SI-Note 2. The MDEC negative-responder (neg) and positive-responder (pos) used here are modified versions of the "negative- and positive-responder" chronologies by Pisaric et al. (2007). The main difference is that the modified MDEC neg and MDEC pos chronologies do not contain Campbell Dolomite Upland series (Szeicz and MacDonald 1996). CDU series were excluded from MDEC neg and MDEC pos to ensure our Group 1/Group 2 correlations with CDU, MDEC neg, and MDEC pos would be independent of each other.

SI-Note 3. The mean NWNA 1/NWNA 2 chronologies were compared to a regional average of CRUTEM3v gridded temperatures (Brohan et al. 2006). The regional average includes $22\left(5^{\circ} \mathrm{x}\right.$ $5^{\circ}$ ) grid cells bounded by $60-70^{\circ} \mathrm{N}$ and $170-115^{\circ} \mathrm{W}$; only 2 grid cells $\left(65-70^{\circ} \mathrm{N} / 160-155^{\circ} \mathrm{W}\right.$ and $65-70^{\circ} \mathrm{N} / 150-145^{\circ} \mathrm{W}$ ) did not contain any data. Temperature data before 1900 were not used as spatial coverage is limited. The number of grid cells with data for the year 1900 is 5; the number of grid cells increases steadily to more than 10 by the early-1920's, more than 15 by the early1940’s, and a high of 20 by 1959 . 